\title{
Phytoplankton spatial distribution patterns along the western Antarctic Peninsula (Southern Ocean)
}

\author{
Irene A. Garibotti ${ }^{1, *}$, María Vernet ${ }^{2}$, Martha E. Ferrario ${ }^{3}$, Raymond C. Smith $^{4}$, \\ Robin M. Ross ${ }^{5}$, Langdon B. Quetin ${ }^{5}$
}

\footnotetext{
${ }^{1}$ Instituto Argentino de Nivología, Glaciología y Ciencias Ambientales, CRICyT, CONICET, CC 330, 5500 Mendoza, Argentina

${ }^{2}$ Scripps Institute of Oceanography, University of California, San Diego, La Jolla, California 92093-0218, USA

${ }^{3}$ Facultad de Ciencias Naturales y Museo, Universidad Nacional de La Plata, 1900 La Plata, Argentina

${ }^{4}$ Institute for Computational Earth System Science and ${ }^{5}$ Marine Science Institute, University of California, Santa Barbara, California 93106, USA
}

\begin{abstract}
This paper describes spatial distribution patterns of the phytoplankton community (composition, cell abundance and biomass concentration) in relation to local environmental conditions in the Southern Ocean. Sampling was performed during summer 1997 off the coast of the western Antarctic Peninsula between Anvers Island and Marguerite Bay. Phytoplankton was characterized by relatively low biomass throughout most of the study area and was dominated by nanoalgae $(<20 \mu \mathrm{m})$. Phytoplankton varied along an on-offshore gradient, with decreasing total cell abundance, chlorophyll $a$ (chl a) concentration and carbon biomass toward the open ocean. Chl a concentration showed surface or subsurface maxima in coastal and middle-shelf waters, and deep maxima between 40 and $100 \mathrm{~m}$ in oceanic waters. Across-shelf variability in phytoplankton correlated with vertical stability in the water column, which appears to be the major parameter affecting phytoplankton community structure in the area. We hypothesize that the deep chl a maximum offshore may be associated with iron limitation in near-surface waters and higher iron concentration in 'winter waters' (subsurface remnant of Antarctic Surface Waters). On a smaller spatial scale, a cluster analysis showed great regional variability in phytoplankton assemblages. The area was divided into 4 main regions based on differences in the phytoplankton composition and concentration. Three peaks in phytoplankton abundance were found on a north-to-south gradient in near-shore waters: a Cryptomonas spp. bloom near Anvers Island, a small unidentified phytoflagellate bloom in Grandidier Channel, and a diatom bloom in Marguerite Bay. These assemblages resemble different stages of the phytoplankton seasonal succession, and may be related to the progressive sea-ice retreat, which might have regulated the timing of the onset of the phytoplankton seasonal succession in a north-south gradient. Biological environmental factors, such as seeding of the water column by epontic algae and selective zooplankton herbivory, are hypothesized to affect community composition in coastal regions. We conclude that large-scale variability in phytoplankton community structure is related to water column physical conditions and possibly iron availability, while mesoscale variability, as seen in coastal waters, is more likely due to seasonal succession of different algae groups.
\end{abstract}

KEY WORDS: Western Antarctic Peninsula $\cdot$ Phytoplankton spatial variability $\cdot$ Seasonal progression • Environmental gradients · Palmer LTER

Resale or republication not permitted without written consent of the publisher

\section{INTRODUCTION}

Early studies in the Southern Ocean suggested that the marine ecosystem has a high autotrophic biomass and primary productivity, and is characterized by a short food chain composed of diatoms $\rightarrow$ krill $\rightarrow$ higher consumers (Smith \& Sakshaug 1990, Marchant \& Murphy 1994). Now it is known that these characteristics are found primarily in inshore, ice-edge and frontal regions (Smith \& Nelson 1985, Tréguer \& Jacques 1992, Bidigare et al. 1996, Bathmann et al. 1997). Throughout most of the Southern Ocean, the auto- 
trophic biomass is low and the base of the food chain is a 'microbial network' of bacteria, phytoplankton and zooplankton (von Bröckel 1981, Marchant \& Murphy 1994). This variability in the structure of the phytoplankton community has important implications for the entire ecosystem, since phytoplankton, as the autotrophic component of the marine ecosystem, affects the structure and efficiency of the food web. Furthermore, the flow of autotrophic carbon through grazing or microbial food webs determines a high or low carbon export to deep waters, and has major relevance in the possible role of the ocean in regulating the global biogeochemical carbon cycle and the atmospheric carbon dioxide drawdown (Priddle et al. 1992, Smetacek 1996, Walsh et al. 2001).

The phytoplanktonic community west of the Antarctic Peninsula (WAP) has been studied extensively. Most studies have concentrated on the Bransfield Strait (Brandini \& Kutner 1986, Holm-Hansen et al. 1994, Priddle et al. 1994, Helbling et al. 1995, Kang \& Lee 1995, Bidigare et al. 1996, Lorenzo et al. 2002), which has complex hydrographic characteristics due to the mixing of water masses of the Drake Passage, Weddell Sea and Bellinghausen Sea (Niiler et al. 1991, Hofmann \& Klinck 1998). South of Bransfield Strait, research was sporadic before the establishment of the 'Palmer Long-Term Ecological Research (LTER) Program' (Smith et al. 1995, Baker et al. 1996), which has been conducting an integrated study of the marine pelagic ecosystem in an area between Anvers Island and Marguerite Bay since 1990 (Fig. 1). This area is distinct from Bransfield Strait because it is entirely occupied by the waters of the Bellingshausen Sea (Hofmann et al. 1996, Hofmann \& Klinck 1998). Therefore, we expected the characteristics of the phytoplankton communities and ecosystem dynamics of Bransfield Strait and southern areas of the Bellingshausen Sea to differ due to their different hydrographic regimes.

Previous results indicated major spatial and temporal variations in the phytoplankton biomass from the area west of the Antarctic Peninsula between Anvers Island and Marguerite Bay. Phytoplankton biomass begins to accumulate in the marginal ice zone during early spring (Holm-Hansen et al. 1989, Bidigare et al. 1996, Moline \& Prézelin 1996, Moline et al. 1997). This high biomass zone moves from the northwest toward the southeast as the sea-ice cover retreats during the spring and summer (Smith et al. 1996, 2001). The summer phytoplankton distribution pattern, as characterized by the chlorophyll a ( $\mathrm{chl}$ a) concentration, shows 2 major concentration gradients, one across-shelf and another along shore, with the coastal and southern zones enriched. Surface chl a data from satellites and a multiyear study done from ships have documented this same pattern for multiple years (Smith et al. 1996, 1998, 2001). These studies concluded that coastal blooms dominated the annual autotrophic production of the area, and that the annual advance and retreat of the pack ice is a major determinant of summer phytoplankton distribution. However, in a recent analysis of this same area during the 1993 summer, Prézelin et al. (2000) stated that phytoplankton dynamics in this area were dominated by episodic diatom blooms in open waters of the continental shelf that were probably related to the intrusion onto the continental shelf and upwelling of the Upper Circumpolar Deep Water (UCDW). These authors concluded that phytoplankton dynamics are non-predictable in the area, and suggested that the zooplankton community and the entire ecosystem dynamics are highly influenced by these upwelling processes. Thus, we lack consensus on the distribution patterns and dynamics of the summer phytoplankton in the area of the western Antarctic Peninsula studied by the Palmer LTER project.

In the present study, we analyzed the composition and biomass of the phytoplankton community during the summer of 1997 in the same mesoscale region as the above studies (Palmer LTER project) (see Fig. 1). The aim of this study was to contribute to the understanding of the structure and dynamics of the Antarctic phytoplanktonic community. Our main question was to what extent do stable patterns or episodic events dominate the dynamics of the phytoplankton in this area. To answer this question, the spatial variability of the community was analyzed in relation to local physical, chemical and biological environmental parameters, and compared to previous studies. Microscopic analyses provided valuable information on phytoplankton taxonomic composition, size-fractions, cell abundance and biomass.

\section{MATERIALS AND METHODS}

The study area is located on the continental shelf west of the Antarctic Peninsula, between 64 and $68^{\circ} \mathrm{S}$ and from the coast to approximately $200 \mathrm{~km}$ offshore. Samples were taken from 5 January to 9 February 1997 at stations located at $20 \mathrm{~km}$ intervals along 5 acrossshelf transect lines plus additional coastal stations (Fig. 1), during the annual Palmer LTER summer cruise on board the RV 'Polar Duke'. Transects are labeled 200 to 600, as explained by Waters \& Smith (1992). At each station, a conductivity-temperature-depth (CTD) rosette package was used to obtain vertical profiles of the physical, optical and biological characteristics of the water column and to collect water samples. CTD measurements were made with a Sea Bird CTD system (SBE 9/11); bio-optical-physical vertical profiles were 
made with a Biospherical Instruments MER 2040 system, and in situ fluorescence profiles were recorded with a SeaTech profiling fluorometer. Discrete water samples were collected with $10 \mathrm{lgo-flow}$ bottles attached to a General Oceanics rosette. The depths of sampling were set at light levels established by measuring photosynthetically active radiation (PAR) using a QSI 240 quantum sensor (Biospherical Instruments). For nutrient and pigment concentration analyses, water aliquots were taken from 6 depths within the euphotic layer $(100,50,30,13,4$ and $0.5 \%$ PAR). For microscopic analyses, they were taken from the $50 \%$ PAR depth.

Water aliquots for measurements of nutrient concentrations were analyzed within $12 \mathrm{~h}$ of sampling. Silicic acid $\left(\mathrm{Si}(\mathrm{OH})_{2}\right)$, nitrate plus nitrite $\left(\mathrm{NO}_{3}{ }^{-}+\mathrm{NO}_{2}{ }^{-}\right)$, and ammonium $\left(\mathrm{NH}_{4}{ }^{+}\right)$concentrations were measured according to the methods described in Johnson et al. (1985), with a Perstorp/Alpken segmented-flow nutrient-analysis system and Labtronics data-collection software. Chl a concentrations were estimated fluorometrically. Water aliquots were filtered through Millipore HA filters $(0.45 \mu \mathrm{m}$ pore size $)$, the filters were extracted in $90 \%$ acetone and stored frozen for $24 \mathrm{~h}$ (Smith et al. 1981). Concentrations of pigments in the acetone were measured with a digital Turner Designs fluoromeer. The fluorometer was calibrated with pure chl a dissolved in $90 \%$ acetone (Sigma).

The water aliquots for microscopic analyses were preserved with $2 \%$ acid Lugol's iodine solution. Microscopic analyses were done as described in Garibotti et al. (2003). Phytoplankton cells were identified and counted with an inverted microscope (Iroscope IS-PH) in settling chambers (Utermöhl 1958). Staining the cells with Lugol's solution allows the recognition of cell contents (e.g. presence of chloroplasts and pyrenoids), and clearer a delineation of the cell outline, favoring the recognition of its shape and size under the microscope (Throndsen 1978). Differentiation between autotrophic and heterotrophic dinoflagellates was done either on the basis of the genus of a known trophic mode or by the clear presence/absence of chloroplasts. Cell biovolumes were measured using the geometric shapes proposed by Hillebrand et al. (1999), and corrected to account for cell shrinkage due to sample fixation (Montagnes et al. 1994). Cell carbon content was calculated with 2 carbon-to-volume ratios, 1 for diatoms (Montagnes \& Franklin 2001) and 1 for all the other algae groups (Montagnes et al. 1994).
Macrozooplankton samples were collected with nets tows at all stations as described by Ross et al. (1998). Trawl contents were analyzed on board for numbers, total wet volumes and size distributions of the 2 macrozooplanktonic grazers that typically dominate in this area, Antarctic krill Euphausia superba and the salp Salpa thompsoni (Quetin et al. 1996). The impacts of grazing by Antarctic krill and salps were calculated with grazing models that allowed us to incorporate the functional response of both grazers to phytoplankton concentrations, and the effect of size on ingestion rates for salps, thus giving a better approximation of zooplankton impact on phytoplankton community than zooplankton abundance alone. To apply the grazing models, the measured wet volume of both krill and salps were converted to wet mass assuming a density of $1 \mathrm{~g} \mathrm{~cm}^{-3}$, and $\mathrm{chl} \mathrm{a}$ concentrations were averaged over the upper $50 \mathrm{~m}$, as most krill and salp biomass appeared to be in this upper portion of the water column (R. M. Ross \& L. B. Quetin unpubl. data). For Antarctic krill we used a linear functional response model of krill ingestion, as described in Ross et al. (1998), and grazing impact was calculated by the product of total krill wet weight, ingestion rate and

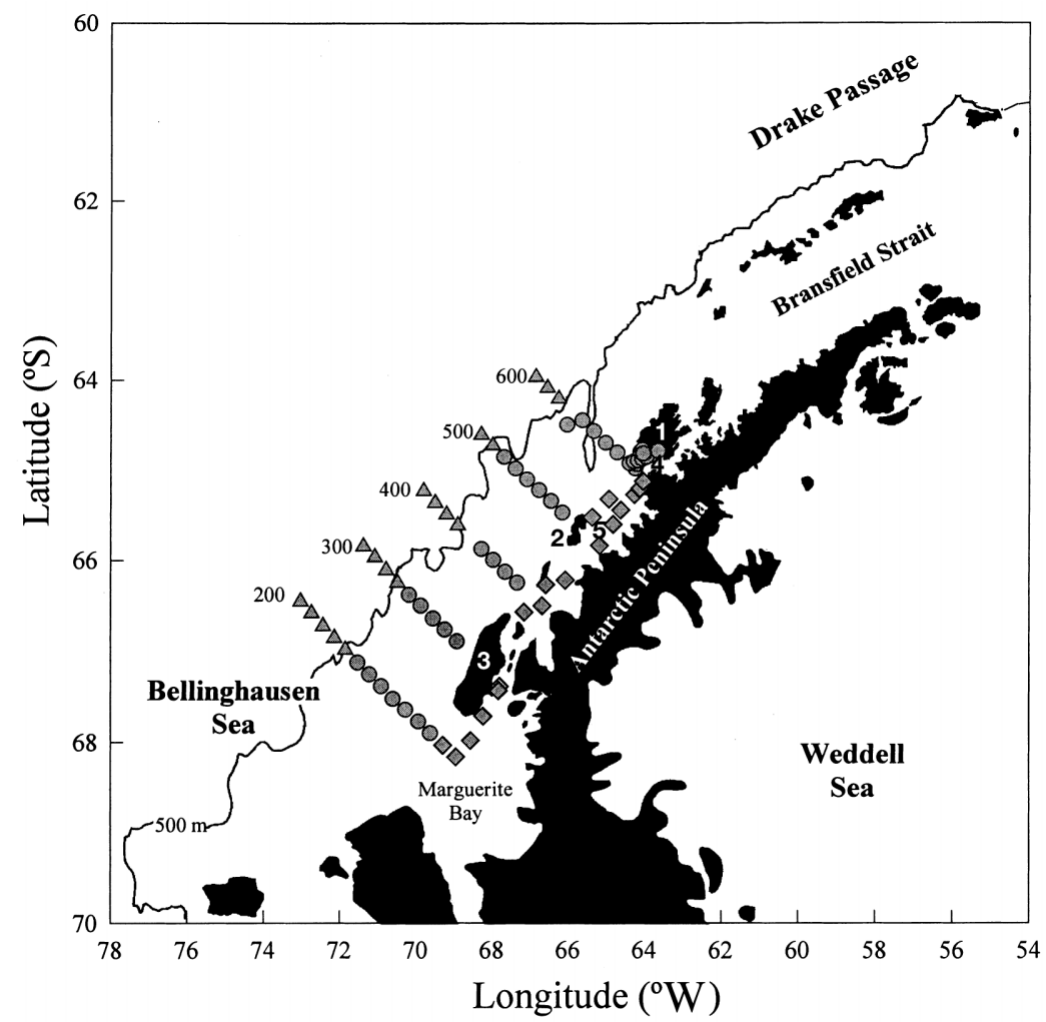

Fig. 1. Location of sampling stations in western coast of Antarctic Peninsula during summer 1997. $(\diamond)$ Coastal region; $(\bullet)$ middle-shelf region; $(\Delta)$ oceanic region. The $500 \mathrm{~m}$ isobath represents continental shelf slope; 200 to 600 are transect numbers. $1=$ Anvers Island, $2=$ Renaud Island, 3 = Adelaide Island, 4 = Bismarck Strait, 5 = Grandidier Channel 
the average chl a concentration in the top $50 \mathrm{~m}$. For salp grazing estimates, the proportion of zooids within 6 defined size categories was estimated from the lengthfrequency distribution of a subsample of zooids. Eleoblasts were not included in the counts of salps, as they are primarily dependent for nutrition on stored reserves. The average filtration rate for each size category was calculated as described in Pakhomov et al. (2002), and the grazing impact due to salps for each station was calculated by multiplying the filtration rate for each size category by the proportion of that size category and the total number of zooids per $\mathrm{m}^{2}$ in the catch, and by the average chl a concentration in the upper $50 \mathrm{~m}$ (Ross et al. 1998). These estimations are first-order approximations of grazing impact, since there are limitations to these grazing models. The krill model does not explicitly include the effect of size on krill ingestion rate, and does not incorporate the known selectivity of Antarctic krill for diatoms (Haberman et al. 2003). The lack of selectivity in the current grazing models is not as much a concern for salps, as they are not believed to be selective feeders (Pakhomov et al. 2002).

Data analysis. Water density was estimated as sigma- $t\left(\sigma_{t}\right)$. The depth of the upper mixed layer (UML) was determined as the depth where a change of $\sigma_{t}$ $>0.05$ occurred over a $5 \mathrm{~m}$ depth interval. Vertical water column stability (E) was calculated according to Mengesha et al. (1998): $\mathrm{E}=d \sigma_{\mathrm{t}} / d z \times 1 / \sigma_{\mathrm{t}(\mathrm{avg})}$ where $\mathrm{d} \sigma_{\mathrm{t}} / \mathrm{dz}$ is the density vertical gradient, $d z$ is $50 \mathrm{~m}$ depth, and $\sigma_{\mathrm{t}(\text { avg })}$ is the average density.

Spatial distribution patterns of the phytoplankton and environmental variables were described from analysis of contour plots generated using the inverse distanceweighting algorithm to interpolate the grid (Jongman et al. 1995). Phytoplanktonic cell abundance and carbon biomass data were from samples at the $50 \%$ PAR depth, presumed to be representative of the UML. This assumption is based on previous studies performed in the area that revealed a uniform vertical distribution of carotenoid pigments (diagnostic of different algae groups), suggesting no major phytoplankton composition variations with depth (Ross et al. 2000, Garibotti et al. 2003). The $50 \%$ PAR depth (5 to $30 \mathrm{~m}$ ) was always within the UML. For other variables, an average value for each station was calculated according to the following criteria. Chl a concentration and nutrient concentrations were averaged over the UML determined for each station. Physicochemical properties of the waters (temperature and salinity) were averaged over the upper $50 \mathrm{~m}$ of the water column, which corresponds to the depth-separating 'winter waters' from the upper water column (Hofmann et al. 1996). It is in this upper portion of the water column that spatial variability in water proprieties can be expected due to the impact of local environmental processes (Hofmann \& Klinck 1998).
Statistical analysis. A cluster analysis was performed on the algae abundances of the different phytoplankton classes to identify groups of stations with similar phytoplankton assemblages. The Bray-Curtis similarity coefficient was used to construct a sample similarity matrix for input to cluster analysis. This coefficient measures the resemblance among phytoplankton assemblages of 2 sites as the sum of the differences of the abundance of each phytoplankton group at each site (Jongman et al. 1995). Abundances were logtransformed so that large counts did not totally dominate the Bray-Curtis similarity coefficient. A completelinkage hierarchical agglomerative clustering procedure was used to group similar samples (Pielou 1984, Jongman et al. 1995).

A canonical correlation analysis was performed to correlate variation in phytoplankton community with the environmental variables. Community variables included algae abundances at the class level (logtransformed) and total chl a concentration. The environmental variables included water column temperature, vertical stability, $\mathrm{Si}(\mathrm{OH})_{2},\left[\mathrm{NO}_{3}{ }^{-}+\mathrm{NO}_{2}{ }^{-}\right]$and $\mathrm{NH}_{4}{ }^{+}$ concentrations, and krill and salp grazing impact. water column salinity and density were not included because they were highly correlated with the water column stability, which was calculated from vertical density changes (see above). The canonical correlation measures the strength of the relationship between 2 sets of variables (ter Braak 1994, Jongman et al. 1995), in this case the phytoplankton and environmental variables. The 2 first significant canonical roots are used to construct the canonical diagram. The canonical roots are the weighted sums of the phytoplankton variables, which are used to calculate the position of the stations in the diagram according to their algae composition, abundance and total biomass. Thus, the distances between stations in the ordination diagram reflect the similarity of their phytoplankton assemblages. Canonical factor loadings are the simple correlations between the environmental variables and the canonical roots, and are considered as a measure of the importance of the different environmental variables determining phytoplankton variability within the area.

\section{RESULTS}

\section{Hydrographic and physicochemical properties}

The main hydrographic feature detected throughout most of the area was the 'winter water' mass, between 50 and $150 \mathrm{~m}$ deep, which disappears only at some shoreward stations located near Anvers Island (in the northeast section of the study area). This water mass, characterized by temperatures below $-1.0^{\circ} \mathrm{C}$ and salin- 
ity values of approximately $34 \mathrm{psu}$, corresponds to the Antarctic Surface Water mass, which is restricted during summer to a deep layer (Hofmann et al. 1996, Hofmann \& Klinck 1998).

The physicochemical properties showed great spatial variability throughout the area. Water temperature and salinity increased gradually from the coast to open ocean, with a maximum degree of change in the zone outlined by the Anvers, Renaud and Adelaide Islands, evidencing the presence of major differences between coastal and open waters (Fig. 2a,b). water column stability also showed a conspicuous gradient, decreasing from the coast toward open waters (Fig. 2c), and the upper mixed layer (UML) depth increased from the coast to open waters (Fig. 2d). Coastal waters had a vertical profile characterized by a steep density gradient with depth and a very shallow mixed layer (UML depth < $15 \mathrm{~m}$ ) (Figs. $2 d$ \& 3a). These characteristics, and the relatively low temperature and salinity of the waters near the coast, indicate freshwater input from sea-ice or glacier melting. In fact, during the sampling period, sea-ice remnants were found in certain stations in the Grandidier Channel, and the sea-ice edge was found in the southern part of Marguerite Bay (Ross \& Baker 1997). Moving progressively away from the coast, the density gradient with depth was less marked, and the upper mixed layer was deeper or not obvious (UML depth > $35 \mathrm{~m}$ ) (Figs. 2d \& 3b,c).

The concentrations measured for all nutrients were relatively high throughout the study area and in the entire water column. However, there was considerable variability within the area (Fig. 4). The $\mathrm{Si}(\mathrm{OH})_{2}$ distribution pattern had a marked onshore-offshore gradient, with higher concentrations near the coast (Fig. 4a). $\mathrm{NO}_{3}{ }^{-}+\mathrm{NO}_{2}{ }^{-}$ showed the opposite pattern, increasing seaward (Fig. 4b). $\mathrm{NH}_{4}{ }^{+}$had a patchy distribution pattern (Fig. 4c). Furthermore, major localized macronutrient depletions were found in certain restricted regions. Specifically, lower $\mathrm{NO}_{3}^{-}+\mathrm{NO}_{2}^{-}$and $\mathrm{Si}(\mathrm{OH})_{2}$ concentrations were found in Marguerite Bay and in the middle of the 500 transect line near Renaud Island and higher $\mathrm{NH}_{4}^{+}$concentrations were found along the 500 transect line and in the Grandidier Channel and Crystal Sound.

\section{Phytoplanktonic community}

Chl a distribution

Distribution of the chl a concentration showed a strong onshore-offshore gradient, decreasing seaward

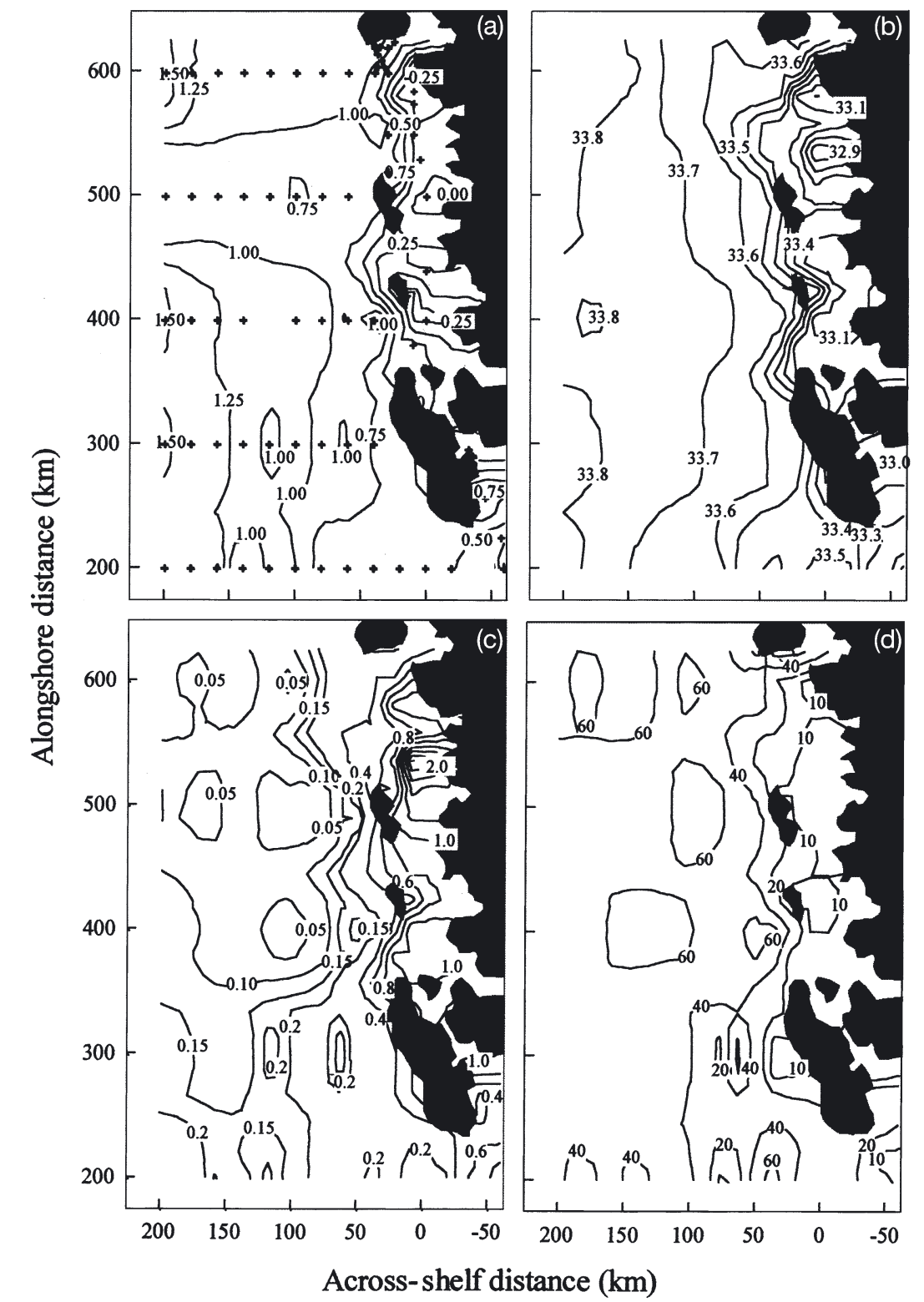

Fig. 2. Physicochemical properties averaged over upper water column $(50 \mathrm{~m})$. (a) Temperature $\left({ }^{\circ} \mathrm{C}\right) ;$ (b) salinity (psu); (c) vertical stability $\left(10^{-3} \mathrm{~m}^{-1}\right)_{i}(\mathrm{~d})$ upper mixed layer depth $\left(\mathrm{m}^{-1}\right)$. Alongshore distance corresponds to transect numbers in Fig. 1, across-shelf distance corresponds to location of stations. Crosses (+) in (a) correspond to sampling stations 


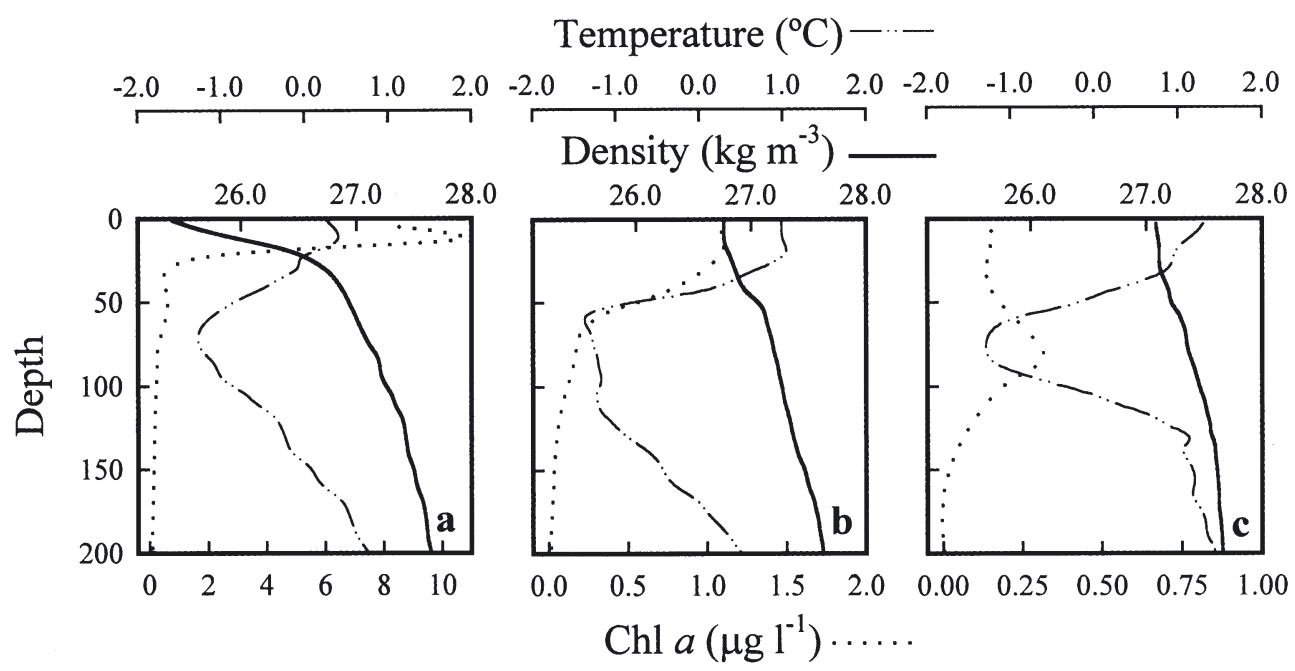

Fig. 3. Vertical profiles of water column temperature, density and chlorophyll a concentration of representative stations of (a) coastal region, (b) middle-shelf region, (c) oceanic region. Regions shown in Fig. 1

(Fig. 5a). The highest concentrations were recorded in Marguerite Bay, with values up to $17.86 \mu \mathrm{g} \mathrm{chl} \mathrm{a} \mathrm{l}^{-1}$, and the lowest in outer shelf waters, reaching a minimum of $0.07 \mu \mathrm{g} \mathrm{chl} \mathrm{a} \mathrm{l}^{-1}$.

Different patterns of chl a distribution with depth were found within the area, and a priori 3 regions were delineated based on their chl a profile with depth: coastal, middle-shelf and oceanic regions (Fig. 1). The coastal region had surface or near-surface chl a peaks (depth $\sim 10 \mathrm{~m}$ ) and very low concentrations in deeper waters (Fig. 3a). The middle-shelf region had nearsurface chl a maxima and a gradual decrease of concentration with depth (Fig. 3b). The oceanic region had low chl a near the surface and higher concentrations between 40 and $100 \mathrm{~m}$ depth (Fig. 3c). These results show that the biomass depth-distribution was deeper moving across the continental shelf toward the slope. Furthermore, chl a vertical profiles closely corre-
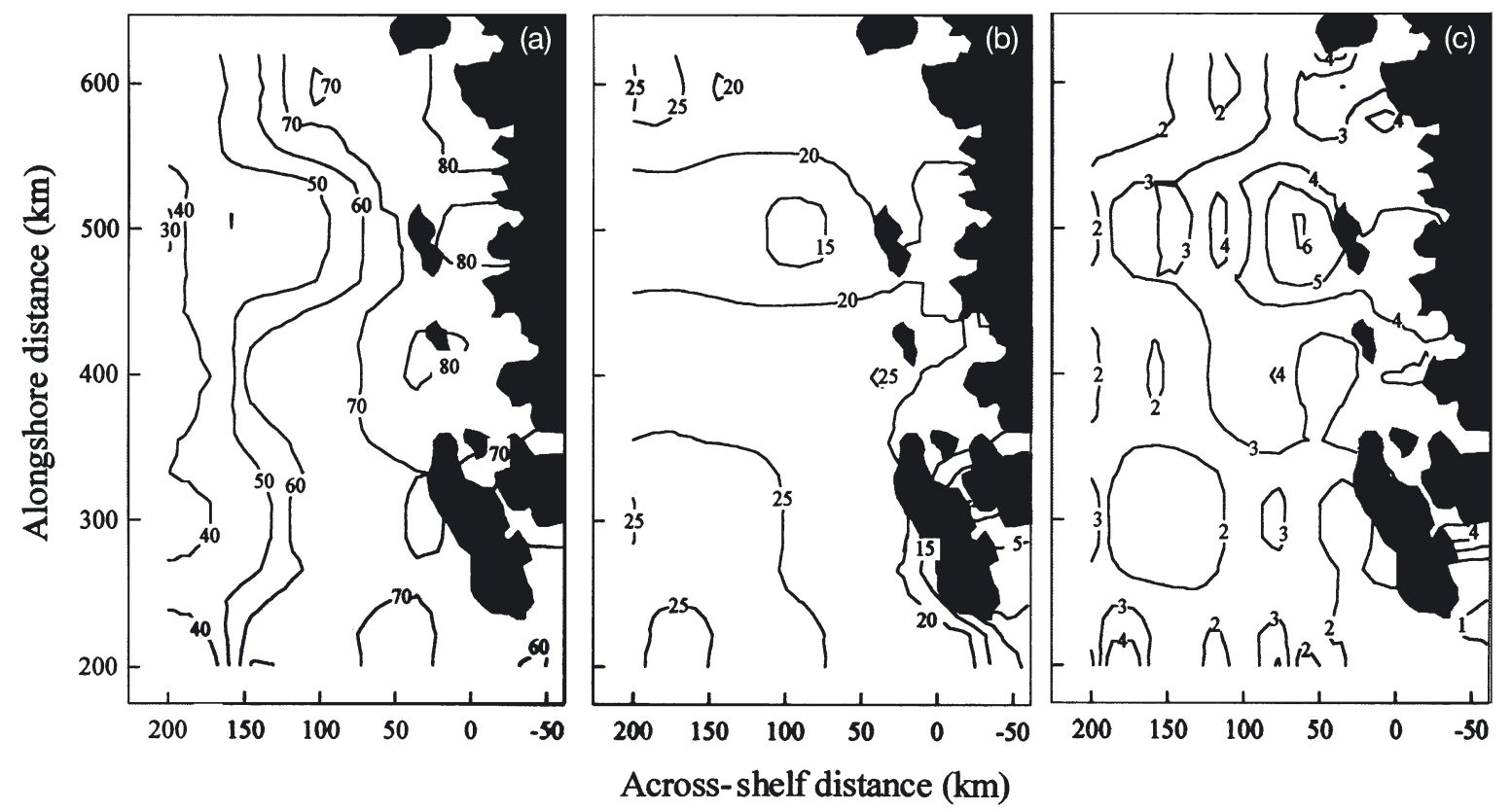

Fig. 4. Distribution of macronutrient concentrations $(\mu \mathrm{M})$ averaged over upper mixed layer. (a) $\mathrm{Si}(\mathrm{OH})_{2} ;$ (b) $\mathrm{NO}_{3}{ }^{-}+\mathrm{NO}_{2}{ }^{-} ;\left(\right.$c) $\mathrm{NH}_{4}{ }^{+}$. Alongshore distance corresponds to transect numbers in Fig. 1; across-shelf distance corresponds to location of stations 

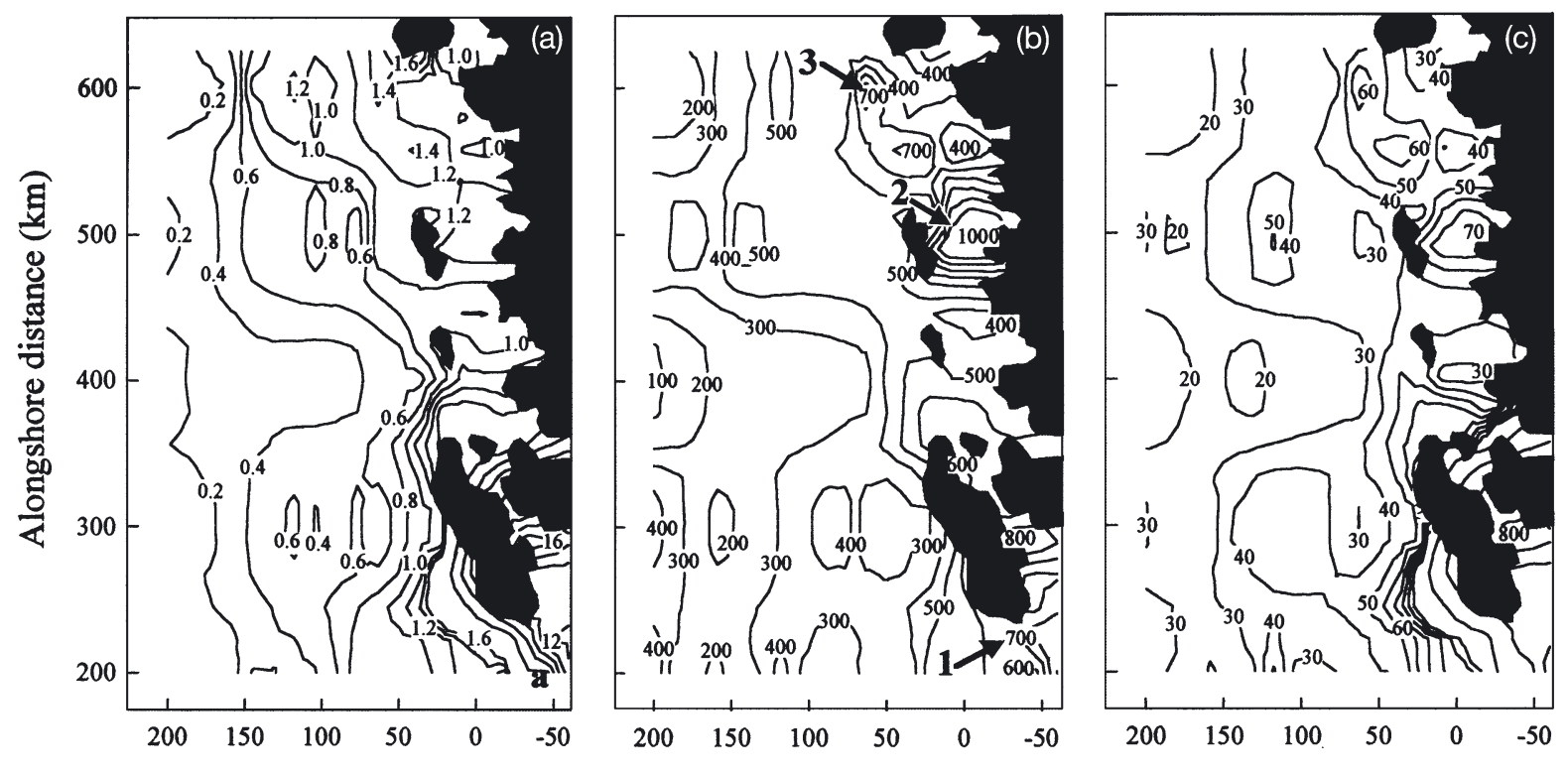

Across-shelf distance $(\mathrm{km})$

Fig. 5. Phytoplankton standing-stock distribution in upper mixed layer: (a) chlorophyll a concentration $\left(\mu \mathrm{g} \mathrm{l}^{-1}\right)$; (b) cell abundance $\left(10^{4} \text { cells } \mathrm{l}^{-1}\right)_{;}$(c) autotrophic carbon concentration $\left(\mu \mathrm{g} \mathrm{l}^{-1}\right)$. Arrows in (b) point to sites with a peak in phytoplankton cell abundance (1: Marguerite Bay; 2: Grandidier Channel; 3: near Anvers Island). Alongshore distance corresponds to transect numbers in Fig. 1, across-shelf distance corresponds to location of stations

sponded to water column physical characteristics (Fig. 3). Average chl a concentrations and physicochemical properties in the upper water column in these regions are shown in Table 1.

\section{Phytoplankton spatial distribution and algae assemblages}

Microscopic analysis showed that the phytoplanktonic community was composed of small unidentified phytoflagellates, cryptophytes, diatoms, prasinophytes, prymnesiophytes and dinoflagellates (Fig. 6). The unidentified phytoflagellate group might include chrysophytes and prymnesiophytes, and a small proportion of chlorophytes and cryptophytes (Garibotti et al. 2003), but here they were pooled together, considering that they have similar ecological importance in the trophic chain. Nanoplanktonic cells $(<20 \mu \mathrm{m})$ dominated throughout most of the area, accounting for $98 \%$ of cell abundance and $41 \%$ of carbon concentration. All phytoplankton groups had nanoplanktonic representatives, while the microphytoplankton $(>20 \mu \mathrm{m})$ was mostly represented by diatoms and dinoflagellates.

The spatial distribution of total phytoplankton cell abundance and carbon biomass (at 50\% PAR depth) showed a remarkable onshore-offshore gradient (Fig. 5b,c), resembling the chl a distribution (Fig. 5a).
Variability in phytoplankton standing stock was high, ranging from 62 to $1150 \times 10^{4}$ cells $\mathrm{l}^{-1}$ and 10 to $967 \mu \mathrm{C} \mathrm{C}^{-1}$. The most outstanding characteristic in the area was the presence of 3 localized peaks in phytoplankton cell abundance in nearshore waters of Marguerite Bay, Grandidier Channel, and the inside of the 600 transect line near Anvers Island (Fig. 5b). In Marguerite Bay, the phytoplankton standing stock reached $938 \times 10^{4}$ cells $\mathrm{l}^{-1}$ (Fig. 5b: Arrow 1) and $967 \mu \mathrm{g} \mathrm{C}^{-1}$ (Fig. 5c). In Grandidier Channel, phytoplankton abundance reached $1147 \times 10^{4}$ cells $\mathrm{l}^{-1}$ (Fig. 5b: Arrow 2), although biomass remained relatively low (maximum

Table 1. Chlorophyll a (chl a) concentration and physicochemical properties: temperature, salinity, density and vertical stability. Average $( \pm \mathrm{SD})$ values for regions differentiated by their phytoplankton vertical distribution (Fig. 1). Values of chl a averaged over upper mixed layer and those of physicochemical properties over upper $50 \mathrm{~m}$ of the water column

\begin{tabular}{|lrrr|}
\hline Parameter & \multicolumn{1}{c}{$\begin{array}{c}\text { Coastal } \\
\text { region }\end{array}$} & \multicolumn{1}{c|}{$\begin{array}{c}\text { Middle-shelf } \\
\text { region }\end{array}$} & \multicolumn{1}{c|}{$\begin{array}{c}\text { Oceanic } \\
\text { region }\end{array}$} \\
\hline Chl $a\left(\mu \mathrm{g} \mathrm{l}^{-1}\right)$ & $4.38 \pm 5.33$ & $0.92 \pm 0.45$ & $0.22 \pm 0.13$ \\
Temperature $\left({ }^{\circ} \mathrm{C}\right)$ & $0.21 \pm 0.48$ & $0.94 \pm 0.23$ & $1.25 \pm 0.27$ \\
Salinity $(\mathrm{psu})$ & $33.14 \pm 0.17$ & $33.64 \pm 0.10$ & $33.79 \pm 0.05$ \\
Density $\left(\mathrm{kg} \mathrm{m}^{-3}\right)$ & $26.59 \pm 0.13$ & $26.95 \pm 0.08$ & $27.05 \pm 0.04$ \\
Vertical stability & $0.90 \pm 0.41$ & $0.18 \pm 0.12$ & $0.12 \pm 0.07$ \\
$\left(10^{-3} \mathrm{~m}^{-1}\right)$ & & & \\
\hline
\end{tabular}



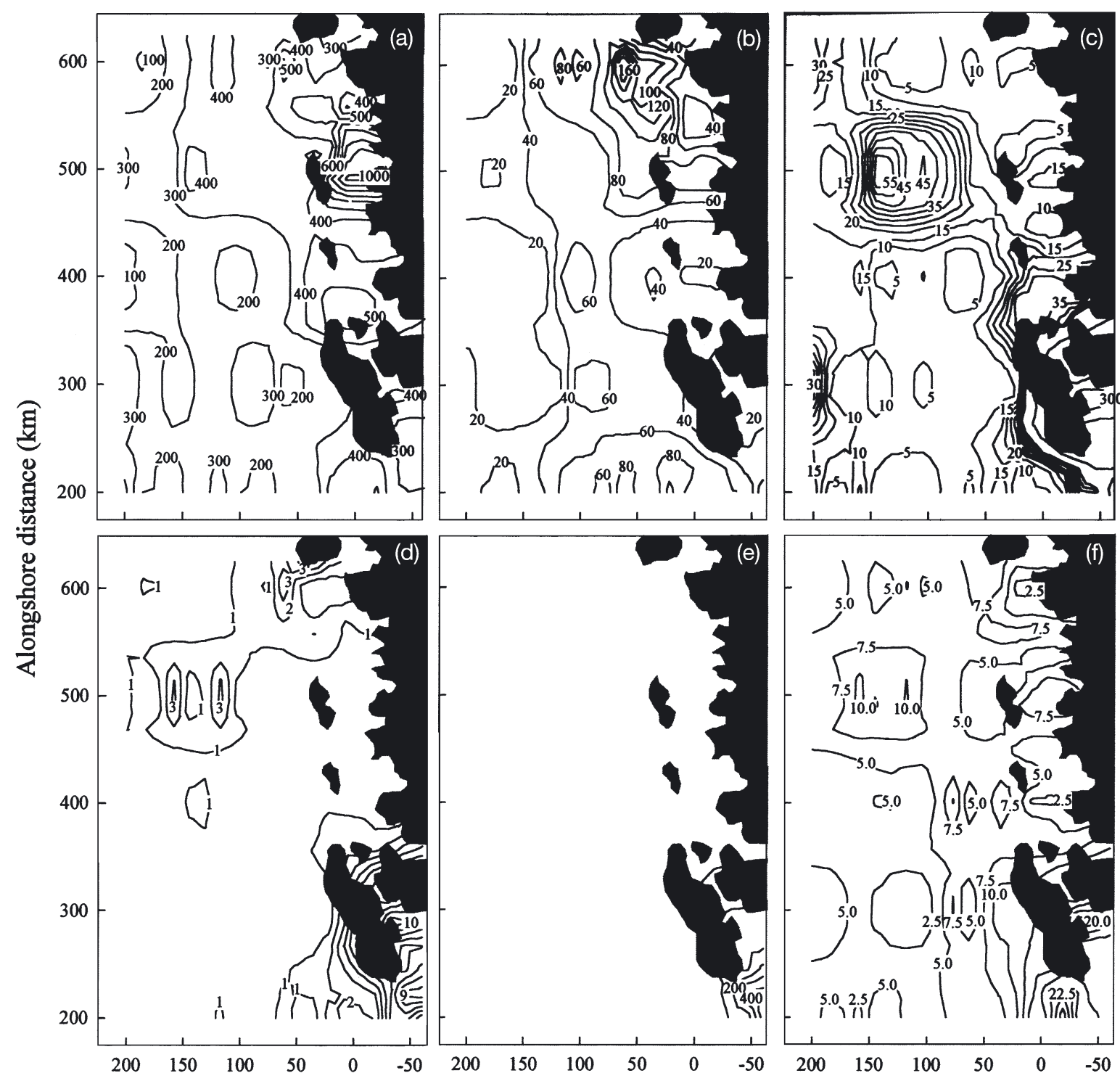

Across-shelf distance $(\mathrm{km})$

Fig. 6. Distribution of major phytoplankton groups in upper mixed layer $\left(10^{4}\right.$ cells $\left.\mathrm{l}^{-1}\right)$. (a) Unidentified phytoflagellates; (b) Cryptomonas spp.; (c) Diatoms; (d) Pyramimonas spp.; (e) Phaeocystis spp.; (f) Dinoflagellates. Alongshore distance corresponds to transect numbers in Fig. 1, across-shelf distance corresponds to location of stations

$79 \mu \mathrm{g} \mathrm{C} \mathrm{l}^{-1}$, Fig. 5c). Near Anvers Island, the peak in cell abundance attained $823 \times 10^{4}$ cells $^{-1}$ (Fig. 5b: Arrow 3), and had relatively low carbon biomass (maximum $83 \mu \mathrm{g} \mathrm{Cl}{ }^{-1}$, Fig. 5c). The number of cells per $\mu \mathrm{g} \mathrm{C}$ was 1 order of magnitude less in Marguerite Bay than elsewhere.

A dendrogram based on the Bray-Curtis coefficient of similarity classified the sampling stations into 4 major groups with over $70 \%$ similarity in their phytoplankton assemblages (algae composition and cell abundance) (Fig. 7a). The Marguerite Bay stations were classified in a separated cluster (Cluster 1) (Fig. 7b), delimiting a region with a homogeneous phytoplankton assemblage (over $80 \%$ similarity). The phytoplankton community of this region was very different from the rest of the study area (separating at $55 \%$ similarity level), and showed the presence of a peak in cell abundance and biomass, as previously described (Table 2, Fig. 5b,c). This was the only region in the entire study area where the microphytoplankton size fraction had high biomass $(88 \% \mathrm{C})$. Diatoms dominated, accounting for $21 \%$ of cell abundance and $86 \%$ 
of C biomass (Fig. 6c). Single-cell Phaeocystis species were also abundant and represented $30 \%$ of cell abundance and $3 \%$ of phytoplankton C (Fig. 6e). Pyramimonas spp. reached also their highest abundance in this region (Fig. 6d). The dominant diatom species were Odontella weisflogii, Eucampia antarctica and Thalassiosira spp. (Table 3). Chaetoceros socialis had a lower carbon concentration, but reached $364 \times 10^{4}$ cells $\mathrm{l}^{-1}$, contributing $58 \%$ of diatom cell abundance.

Cluster 2 (Fig. 7a) included the stations located on the shelf slope and off the continental shelf (Fig. 7b), delimiting a region with a homogeneous phytoplankton assemblage (over $75 \%$ similarity), separating from the rest of the area at an approximately $60 \%$ similarity level. Stations in Cluster 2 corresponded to those in the oceanic region, as delimited previously by the chl a vertical distribution pattern (cf. Figs. $1 \&$ 7b). Thus, the region delimited by Cluster 2 is also named oceanic region. The phytoplankton assemblage was dominated by unidentified phytoflagellates, accounting for $85 \%$ cell abundance and 28\% C biomass (Fig. 6a, Table 2). Although diatoms and dinoflagellates had relatively low abundance (6 and $2 \%$ respectively), they contributed 27 and $21 \%$ of the total carbon biomass respectively (Table 2). The most important diatom species were Corethron criophyllum, small Fragilariopsis curta, F. cylindrus and F. pseudonana, Nitzschia spp. and Thalassiosira spp. (Table 3). The 3 species of small Fragilariopsis together represented $88 \%$ of diatom cell abundance.

The stations located in the middle continental shelf and in the Grandidier Channel and Crystal Sound were a mosaic of Clusters 3 and 4 (Fig. 7a). The spatial distribution of the stations included in these clusters overlapped, making difficult the delimitation of other regions with a homogeneous phytoplankton assemblage within the area. Furthermore, the stations included in the Cluster 4 were divided into 3 smaller clusters with a very high similarity in their phytoplankton assemblages (Fig. 7a).

Cluster $4 \mathrm{~b}$ included stations with over $85 \%$ of similarity in their phytoplankton assemblages (Fig. 7a), which were located in 3 regions spatially distinct from each other (Fig. 7b). Based on their location, these 3 regions were named near
Adelaide Island (inside the Transect 200 and 300 lines), Grandidier Channel (inshore between the Transect 500 and 600 lines) and near Anvers Island (inside the Transect 600 line) (Fig. 7b). Of these, 2 regions (Grandidier Channel and near Anvers Island) had a peak in cell abundance (Fig. 5b). The characteristics of the phytoplankton assemblages (Cluster $4 \mathrm{~b}$ ) were the dominance of unidentified phytoflagellates (representing $82 \%$ cell abundance and $35 \%$ carbon biomass) and the very high abundance of cryptophytes (contributing $15 \%$ of cell abundance and $30 \%$ of the carbon biomass) (Table 2, Fig. 6a,b). Furthermore, these assemblages had a low proportion of diatoms, which accounted for only $1 \%$ of cell abundance and $13 \%$ of carbon biomass (Fig. 6c, Table 3). The dominant diatom species were Corethron
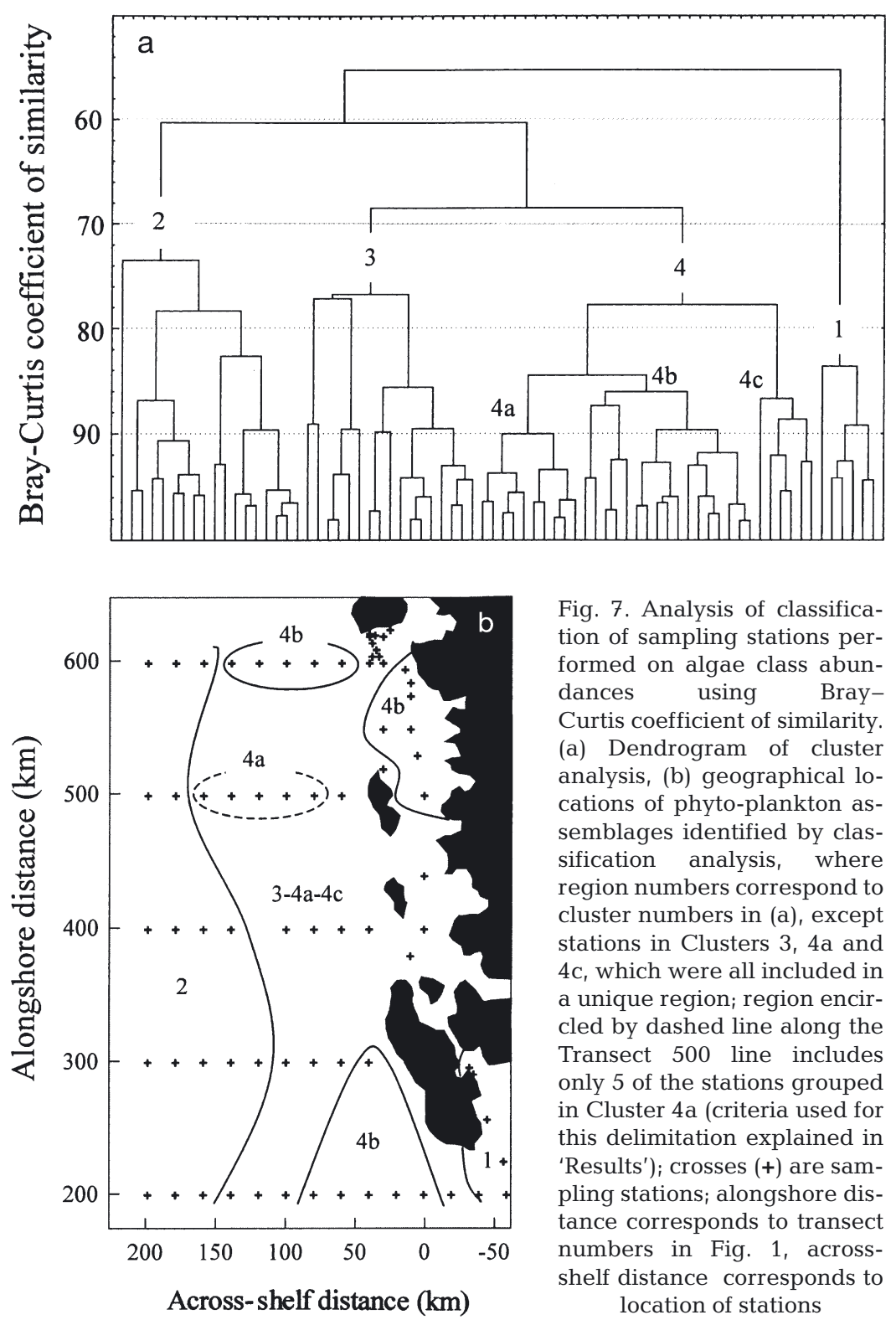

Fig. 7. Analysis of classification of sampling stations performed on algae class abundances using BrayCurtis coefficient of similarity. (a) Dendrogram of cluster analysis, (b) geographical locations of phyto-plankton assemblages identified by classification analysis, where region numbers correspond to cluster numbers in (a), except stations in Clusters 3,4a and $4 \mathrm{c}$, which were all included in a unique region; region encircled by dashed line along the Transect 500 line includes only 5 of the stations grouped in Cluster 4a (criteria used for this delimitation explained in 'Results'); crosses (+) are sampling stations; alongshore distance corresponds to transect numbers in Fig. 1, acrossshelf distance corresponds to location of stations 
Table 2. Phytoplanktonic community structure. Chlorophyll a concentration $\left(\mu \mathrm{g} \mathrm{l}^{-1}\right)$, cell abundance $\left(10^{4}\right.$ cells $\left.\mathrm{l}^{-1}\right)$ and carbon biomass $\left(\mu \mathrm{g} \mathrm{C}^{-1}\right.$ ) for total phytoplankton and for dominant phytoplankton groups. Average $\pm \mathrm{SD}$ values for regions delimited by classification analysis of phytoplankton assemblages (Fig. 7). Values of chl a averaged over upper mixed layer and those of phytoplankton standing stock are from samples at $50 \%$ PAR depth

\begin{tabular}{|c|c|c|c|c|}
\hline Parameter & $\begin{array}{c}\text { Region } 1 \\
\text { (Marguerite Bay) }\end{array}$ & $\begin{array}{c}\text { Region } 2 \\
\text { (oceanic region) }\end{array}$ & $\begin{array}{l}\text { Region } 4 \mathrm{~b} \\
\text { (3 regions) }\end{array}$ & $\begin{array}{c}\text { Region } 3 \\
\text { (central region) }\end{array}$ \\
\hline Chlorophyll a & $10.82 \pm 4.65$ & $0.23 \pm 0.16$ & $1.11 \pm 0.29$ & $0.88 \pm 0.50$ \\
\hline \multicolumn{5}{|l|}{ Total phytoplankton } \\
\hline Cells & $733 \pm 175$ & $253 \pm 115$ & $525 \pm 234$ & $405 \pm 119$ \\
\hline Biomass & $603 \pm 224$ & $25 \pm 11$ & $48 \pm 17$ & $40 \pm 17$ \\
\hline \multicolumn{5}{|c|}{ Unidentified phytoflagellates } \\
\hline Cells & $306 \pm 77$ & $216 \pm 103$ & $431 \pm 218$ & $326 \pm 106$ \\
\hline Biomass & $8 \pm 6$ & $7 \pm 3$ & $16 \pm 8$ & $12 \pm 5$ \\
\hline \multicolumn{5}{|l|}{ Cryptomonas spp. } \\
\hline Cells & $24 \pm 20$ & $15 \pm 10$ & $77 \pm 41$ & $54 \pm 27$ \\
\hline Biomass & $3 \pm 2$ & $2 \pm 2$ & $14 \pm 8$ & $9 \pm 5$ \\
\hline \multicolumn{5}{|l|}{ Diatoms } \\
\hline Cells & $154 \pm 137$ & $44 \pm 15$ & $8 \pm 5$ & $13 \pm 6$ \\
\hline Biomass & $520 \pm 221$ & $7 \pm 5$ & $6 \pm 6$ & $8 \pm 7$ \\
\hline \multicolumn{5}{|l|}{ Pyramimonas spp. } \\
\hline Cells & $7 \pm 3$ & 0 & $1 \pm 1$ & $1 \pm 2$ \\
\hline Biomass & $1 \pm 1$ & 0 & 0 & 0 \\
\hline \multicolumn{5}{|l|}{ Phaeocystis spp. } \\
\hline Cells & $220 \pm 186$ & $1 \pm 3$ & 0 & $2 \pm 7$ \\
\hline Biomass & $19 \pm 16$ & 0 & 0 & $0 \pm 1$ \\
\hline \multicolumn{5}{|l|}{ Dinoflagellates } \\
\hline Cells & $14 \pm 5$ & $4 \pm 2$ & $7 \pm 4$ & $7 \pm 5$ \\
\hline Biomass & $18 \pm 5$ & $5 \pm 2$ & $8 \pm 4$ & $7 \pm 6$ \\
\hline
\end{tabular}

criophyllum, Thalassiosira spp. and small Fragilariopsis curta, F. cylindrus and F. pseudonana (Table 2). The 3 small Fragilariopsis species accounted for $72 \%$ of the diatom cell abundance.

Cluster 4a (Fig. 7a) delimited a group of stations seaward of Renaud Island (along the central part of the Transect 500 line) (Fig. 7b), which displayed over $90 \%$ of similarity in their phytoplankton assemblages. The outstanding characteristic of these stations was an increment in the abundance of unidentified phytoflagellates, diatoms, dinoflagellates and prasinophytes (Fig. 6). The 3 former phytoplankton groups contributed almost the same proportion of biomass $(27,23$ and $25 \%$ C respectively). Diatom species more common in this region were small Fragilariopsis curta, F. cylindrus and F. pseudonana, Corethron criophyllum and Nitzschia spp. The other stations grouped in Cluster 4 a corresponded to the Bismarck Strait (nearshore on the Transect 600 line), indicating a close similarity between the phytoplankton assemblage of the near Renaud Island region and that of Bismarck Strait. However, this latter location also included other stations classified as Cluster 3, indicating a more heterogeneous phytoplankton assemblage.

Therefore, since the stations in Clusters 3, 4a and 4c did not group in a well-defined region, they were all combined into a large central region (Fig. 7b). The phytoplankton assemblage of this region was domi- nated by unidentified phytoflagellates, which contributed with $81 \%$ of cell abundance and $31 \%$ of the C biomass (Fig. 6a, Table 2). Cryptomonas spp. were also important throughout this region, with $13 \%$ of cell abundance and $23 \%$ of $\mathrm{C}$ biomass, and diatoms and dinoflagellates had a low abundance (3 and 2\% respectively) but made a high contribution to total biomass (19\% C each) (Table 2). The most important diatom species were Corethron criophyllum, small Fragilariopsis curta, F. cylindrus and F. pseudonana, Nitzschia spp. and Thalassiosira spp. (Table 3).

In summary, there was a change in phytoplankton standing stock along an onshore-offshore gradient, showing a decreasing abundance and biomass toward the open ocean (Fig. 5). Most algae groups were ubiquitous in the area, except prymnesiophytes and prasinophytes, which had restricted distributions (Fig. 6). However, the phytoplankton also had high variability on a smaller spatial scale, and different regions were delimited based on their similarity in phytoplankton composition and abundance (Fig. 7). The cluster analysis confirmed the similarity of phytoplankton assemblages at stations with a deep chl a maximum, delimiting the oceanic region. In contrast, the stations with maximum surface chl a (Fig. 3b,c) were classified in different clusters, indicating that these stations (grouped a priori in a coastal and a 
Table 3. Diatom populations. Composition and biomass ( $\mu \mathrm{g} \mathrm{C}$ $\mathrm{l}^{-1}$ ) of species that contributed $>1 \%$ of total diatom carbon biomass. Average \pm SD values for regions delimited by classification analysis of phytoplankton assemblages (Fig. 7). Cell size given in parentheses

\begin{tabular}{|c|c|}
\hline Region & Biomass \\
\hline \multicolumn{2}{|l|}{ Region 1 (Marguerite Bay) } \\
\hline Odontella weisflogii & $298.0 \pm 160.0$ \\
\hline Eucampia antartica & $96.0 \pm 70.7$ \\
\hline Thalassiosira spp. $(50 \mu \mathrm{m})$ & $41.8 \pm 46.7$ \\
\hline Chaetoceros socialis & $19.5 \pm 31.6$ \\
\hline Fragilariopsis curta $(40 \mu \mathrm{m})$ & $14.3 \pm 11.8$ \\
\hline Nitzschia spp. $(60 \mu \mathrm{m})$ & $11.6 \pm 14.0$ \\
\hline Chaetoceros dichaeta & $5.8 \pm 7.7$ \\
\hline \multicolumn{2}{|l|}{ Region 2 (oceanic region) } \\
\hline Corethron criophyllum & $2.9 \pm 5.0$ \\
\hline Small Fragilariopsis spp. ${ }^{a}$ & $1.4 \pm 1.1$ \\
\hline Nitzschia spp. $(60 \mu \mathrm{m})$ & $0.8 \pm 1.5$ \\
\hline Thalassiosira spp. $(25 \mu \mathrm{m})$ & $0.6 \pm 2.7$ \\
\hline Fragilariopsis curta $(40 \mu \mathrm{m})$ & $0.3 \pm 0.7$ \\
\hline Thalassiosira spp. $(15 \mu \mathrm{m})$ & $0.2 \pm 0.7$ \\
\hline Fragilariopsis separanda & $0.1 \pm 0.3$ \\
\hline \multicolumn{2}{|l|}{ Region 4b (3 regions) } \\
\hline Corethron criophyllum & $4.19 \pm 4.7$ \\
\hline Thalassiosira spp. $(25 \mu \mathrm{m})$ & $0.7 \pm 1.9$ \\
\hline Small Fragilariopsis spp. ${ }^{a}$ & $0.6 \pm 0.5$ \\
\hline Chaetoceros spp. $(15 \mu \mathrm{m})$ & $0.4 \pm 1.1$ \\
\hline Nitzschia spp. $(60 \mu \mathrm{m})$ & $0.2 \pm 0.4$ \\
\hline Fragilariopsis separanda & $0.2 \pm 0.3$ \\
\hline Cylindrotheca closterium & $0.1 \pm 0.2$ \\
\hline \multicolumn{2}{|l|}{ Region 3 (central region) } \\
\hline Corethron criophyllum & $3.0 \pm 5.8$ \\
\hline Thalassiosira spp. $(25 \mu \mathrm{m})$ & $1.4 \pm 2.7$ \\
\hline Nitzschia spp. $(60 \mu \mathrm{m})$ & $1.3 \pm 1.6$ \\
\hline Small Fragilariopsis spp. ${ }^{a}$ & $1.2 \pm 1.7$ \\
\hline Unidentified pennal $(60 \mu \mathrm{m})$ & $0.2 \pm 1.0$ \\
\hline Chaetoceros spp. $(15 \mu \mathrm{m})$ & $0.2 \pm 0.7$ \\
\hline Fragilariopsis curta $(40 \mu \mathrm{m})$ & $0.1 \pm 0.5$ \\
\hline Nitzschia spp. (30 um) & $0.1 \pm 0.1$ \\
\hline Thalassiosira spp. $(15 \mu \mathrm{m})$ & $0.1 \pm 0.5$ \\
\hline
\end{tabular}

middle-shelf region) did not have an homogeneous phytoplankton composition. The physicochemical properties of the upper water column in the regions delimited by the cluster analysis are shown in Table 4.

\section{Zooplanktonic community}

Both Antarctic krill and salps were abundant in the northern half of the area in January 1997, with small isolated areas of elevated abundance in the southern half of the region surveyed (Table 4, Fig. 8a,b). However, the 2 species showed less coherence on smaller spatial scales, as areas of highest abundance did not overlap, i.e. seaward of Renaud Island and in Crystal Sound for krill and mid-shelf on the Transect 600 line and inland Renaud Island for salps (Fig. 8). Krill abundance also showed an onshore-offshore gradient, with higher abundance in the middle-shelf and coastal regions, and relatively low abundance throughout the oceanic region (Fig. 8a). The pattern of distribution of salps showed high concentrations in the northern region at the coastal stations, but they were also consistently found in lower numbers at stations in the oceanic region (Fig. 8b).

Although the grazing impact shared some of the distribution patterns of abundance of the grazers alone, the differences illustrate the value of the grazing models (Fig. 8c,d). Krill grazing impact was highest in the coastal region, and null throughout the oceanic region, as phytoplankton biomass was lower than the threshold for krill ingestion $\left(0.36 \mu \mathrm{g} \mathrm{chl} \mathrm{al}^{-1}\right.$, Ross et al. 1998). The highest grazing impact was estimated for stations in the Grandidier Channel, with grazing lower in the 2 other regions with a similar phytoplankton assemblage (near Adelaide Island and near Anvers Island). Grazing impact was also lower at stations in Marguerite Bay (Cluster 1) and near Renaud Island (Cluster 4a). Salp

Table 4. Physical, chemical and biological environmental variables. Temperature $\left({ }^{\circ} \mathrm{C}\right)$, salinity $(\mathrm{psu})$, density $\left(\mathrm{kg} \mathrm{m}^{-3}\right)$, vertical

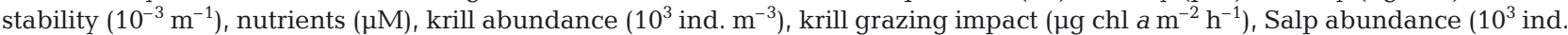
$\left.\mathrm{m}^{-3}\right)$, and salp grazing impact $\left(\mu \mathrm{g} \mathrm{chl} a \mathrm{~m}^{-2} \mathrm{~h}^{-1}\right)$. Average \pm SD values for regions differentiated in Fig. 7. Values of physicochemical properties averaged over upper $50 \mathrm{~m}$ of water column, and nutrients averaged over upper mixed layer

\begin{tabular}{|lcccc|}
\hline Parameter & Region 1 (Marguerite Bay) & Region 2 (oceanic region) & Region 4b (3 regions) & Region 3 (central region) \\
\hline Temperature & $0.37 \pm 0.47$ & $1.26 \pm 0.26$ & $0.57 \pm 0.54$ & $0.84 \pm 0.42$ \\
Salinity & $33.13 \pm 0.14$ & $33.80 \pm 0.03$ & $33.38 \pm 0.27$ & $33.59 \pm 0.20$ \\
Density & $26.58 \pm 0.10$ & $27.06 \pm 0.03$ & $26.77 \pm 0.20$ & $26.92 \pm 0.15$ \\
Vertical stability & $0.79 \pm 0.30$ & $0.12 \pm 0.07$ & $0.53 \pm 0.55$ & $0.27 \pm 0.27$ \\
$\mathrm{Si}(\mathrm{OH})_{2}$ & $57.96 \pm 3.38$ & $47.48 \pm 9.70$ & $78.28 \pm 6.09$ & $70.18 \pm 12.05$ \\
$\mathrm{NO}_{3}{ }^{+}+\mathrm{NO}_{2}{ }^{-}$ & $5.14 \pm 5.00$ & $25.01 \pm 3.15$ & $21.93 \pm 2.64$ & $22.22 \pm 4.07$ \\
$\mathrm{NH}_{4}^{+}$ & $1.62 \pm 0.89$ & $1.98 \pm 1.23$ & $2.68 \pm 1.13$ & $2.80 \pm 1.14$ \\
$\mathrm{Krill}_{\text {abundance }}$ & $9 \pm 5$ & $21 \pm 33$ & $8.88 \pm 14.69$ & $205 \pm 378$ \\
Krill grazing impact & $5.16 \pm 3.87$ & 0 & $37 \pm 59$ & $3.54 \pm 8.90$ \\
Salp abundance & 0 & $22 \pm 33$ & $16.99 \pm 25.63$ & $28 \pm 39$ \\
Salp grazing impact & 0 & $1.95 \pm 3.72$ & $7.99 \pm 14.71$
\end{tabular}




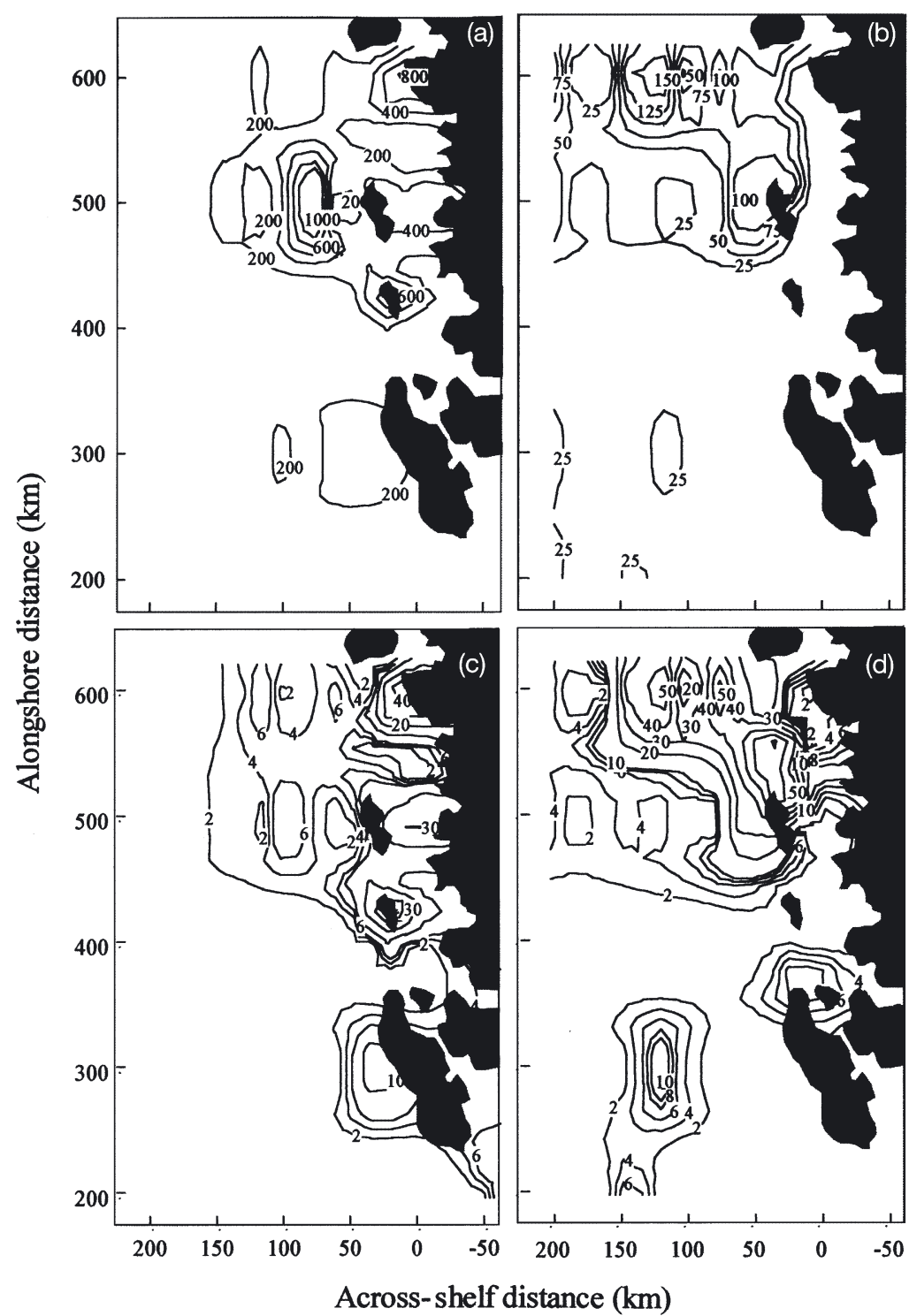

Fig. 8. Zooplanktonic community. (a) Abundance of Euphausia superba $\left(10^{3}\right.$ ind. $\left.\mathrm{m}^{-3}\right)$; (b) abundance of Salpa thompsoni $\left(10^{3}\right.$ ind. $\left.\mathrm{m}^{-3}\right)$; (c) grazing

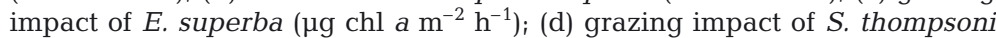
$\left(\mu \mathrm{g} \mathrm{chl} \mathrm{a} \mathrm{m}^{-2} \mathrm{~h}^{-1}\right.$ ). Alongshore distance corresponds to transect numbers in

Fig. 1, across-shelf distance corresponds to location of stations

grazing impact, on the other hand, appeared to be higher on the middle shelf, both north and south, and in the Grandidier Channel, coinciding with high unidentified phytoflagellates and cryptophyte abundance, and low diatom abundance (Figs. 6 \& 8d).

\section{Phytoplankton spatial distribution and related environmental gradients}

A canonical correlation analysis was used to evaluate the linkage of phytoplankton community structure to environmental parameters. The Marguerite Bay stations were not included in the analysis since they showed extreme values for all variables, and the canonical correlation analysis performs better on an homogeneous data set (ter Braak 1994, Jongman et al. 1995).

The canonical correlation was significant and high ( $\left.\mathrm{p}<0.001 ; \mathrm{R}^{2}=0.82\right)$, indicating a close relationship between the phytoplankton and the environmental variables analyzed. We extracted 2 significant canonical roots that cumulatively explained $42 \%$ of the variance observed. Ordination of the samples in the first 2 canonical roots shows the separation of stations of the coastal, middle-shelf and oceanic regions (Fig. 9), as defined by their chl a profile (Figs. 1 \& 3). Although partly overlapping, the separation of the 3 regions is more evident along the first canonical root. The coastal region has negative values on the first canonical root, the middle-shelf region has values around zero, and the oceanic region has positive values. The second canonical root also contributes to the separation of the regions, showing mostly negative values for the middle-shelf region, and positive values for the other 2 regions. Since distance between stations in the ordination diagram correspond to the level of similarity among stations (ter Braak 1994), the first canonical root can be interpreted as indicating a gradual change of the phytoplankton structure from the coast to open regions. However, there is high variability within the coastal, middleshelf and oceanic regions along the second canonical root, possibly representing the great regional variability found in the phytoplankton composition and abundance within the 3 regions, as previously described from the analysis of the contour plots and the cluster analysis.

water column stability had a high correlation with both canonical roots (Table 5), indicating the high influence of this variable on phytoplankton variability throughout the area. On the other hand, temperature and $\mathrm{Si}(\mathrm{OH})_{2}$ concentration showed high correlation with the first canonical root only, indicating their major relation with the onshore-offshore phytoplankton changes. The other variables analyzed (other nutrients and macrozooplanton grazing impact) have lower influence on the variability of the phytoplankton throughout the area, as indicated by their low correlation with the 2 significant canonical roots. 


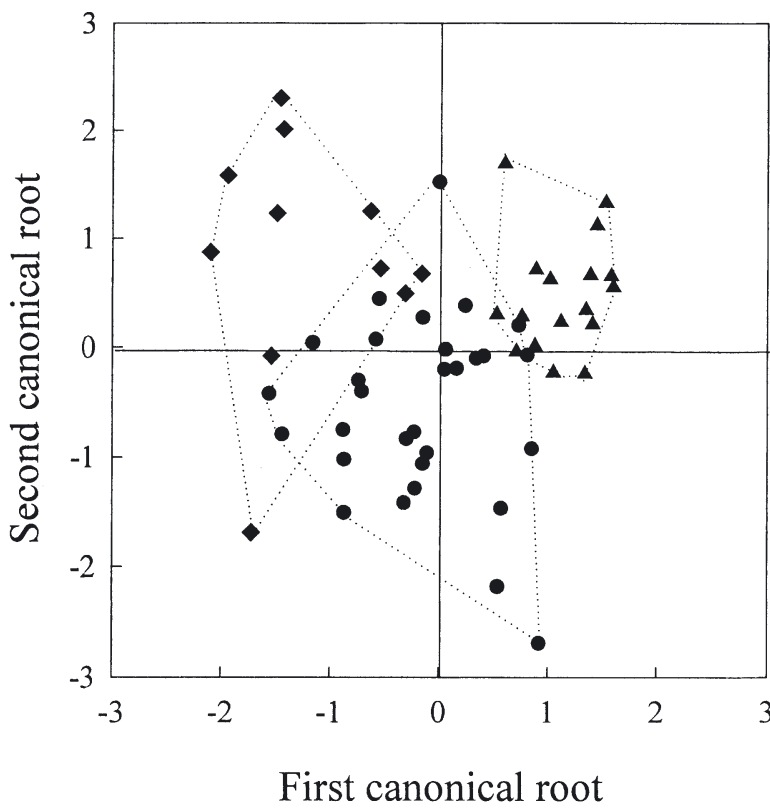

Fig. 9. Ordination diagram of canonical correlation analysis of phytoplankton community in study area. Region symbols as in Fig. 1. Canonical correlation $\left(\mathrm{R}^{2}\right)=0.82$. Scale corresponds to stations scores according to their phytoplankton structure (algae composition, cell abundance and chl a concentration). See Table 5 for correlation of environmental variables with the 2 canonical roots

\section{DISCUSSION}

\section{Across-shelf phytoplankton distribution pattern}

The results of this study show that the western Antarctic Peninsula, influenced by Bellinghausen Sea water and seasonally swept by sea-ice, is an area where large- and meso-spatial scales are needed to explain phytoplankton community structure and dynamics. During January 1997, phytoplankton biomass was low throughout most of the area (Fig. 5) and was dominated by nanoplanktonic-size cells, as appears to be typical for most of the Southern Ocean (von Bröckel 1981, Weber \& El-Sayed 1987). High biomass concentration was only found associated with the sea-ice edge in Marguerite Bay (Fig. 5, Table 2), emphasizing the importance of ice-edges as areas of enhanced phytoplankton biomass in the Southern Ocean (Smith \& Nelson 1985, Bianchi et al. 1992, Bidigare et al. 1996).

Chl a concentration, phytoplankton cell abundance and carbon biomass showed great variability along an onshore-offshore gradient (Fig. 5, Table 1). The gradients in carbon biomass and chl a concentration were of the same magnitude as others previously reported for this area (Smith et al. 1998, 2001, Garibotti et al. 2003), showing phytoplankton standing stocks several times higher in coastal waters than in open waters (Table 1). Composition of the phytoplanktonic community and diatom populations also changed along the gradient, as indicated by shifts in the dominant algae groups and diatom species in regions differentiated within the area (Fig. 6, Tables $2 \& 3$ ). Contrary to many previous reports in which Antarctic waters were characterized with a gradient in cell size, from nanophytoplankton in offshore regions to microphytoplankton in onshore regions (Smetacek et al. 1990, Baker et al. 1996, Bidigare et al. 1996), in January 1997 both nano- and microplanktonic phytoplankton groups were more abundant inshore, and both decreased in abundance and biomass toward the open ocean (Fig. 6).

The variability in phytoplankton structure along an onshore-offshore gradient was also revealed by the canonical analysis (Fig. 9), which showed that phytoplankton composition and abundance variability was closely related to changes in water column stability (Table 5). Thus, it appears that water column stability is a major environmental factor regulating phytoplankton composition and standing stock throughout the area, as previously reported for other areas of the western Antarctic Peninsula (Holm-Hansen et al. 1989, Mitchell \& Holm-Hansen 1991, Kang \& Lee 1995). water column stabilization and restricted mixing regulate total phytoplankton standing stock by allowing cells to remain in the upper water column under a favorable light regime and preventing their sedimentation (Smith \& Sakshaug 1990). The cold waters with low salinity near the coast (Fig. 2) and their steep density change with depth (Fig. 3a) showed that the water column was stabilized by the influence of sea-ice and/or glacier meltwater at the inner-shelf stations. In addition, island protection from storms (Hofmann et al. 1996) may have favored the marked stratification observed near the coast (Figs. 2c,d \& 3a).

The canonical analysis assigned high factor loadings for the water column temperature and macronutrient concentration (Table 5), suggesting that variability in

Table 5. Factor loadings of environmental variables, which are simple correlations with canonical roots estimated by canonical correlation analysis in Fig. 9

\begin{tabular}{|lcr|}
\hline Parameter & $\begin{array}{c}\text { First canonical } \\
\text { root }\end{array}$ & $\begin{array}{c}\text { Second canonical } \\
\text { root }\end{array}$ \\
\hline Temperature & 0.66 & -0.42 \\
Vertical stability & -0.63 & 0.67 \\
$\mathrm{Si}(\mathrm{OH})_{2}$ & -0.79 & -0.32 \\
$\mathrm{NO}_{3}{ }^{+}+\mathrm{NO}_{2}{ }^{-}$ & 0.38 & -0.36 \\
$\mathrm{NH}_{4}{ }^{+}$ & -0.21 & 0.04 \\
$\mathrm{Krill}_{\text {grazing impact }}$ & -0.38 & 0.24 \\
Salp grazing impact & -0.50 & -0.39 \\
\hline
\end{tabular}


phytoplankton composition and standing stock throughout the onshore-offshore gradient was also closely related to these variables. However, although temperature can limit algal growth rates and productivity, polar temperatures are below the optimum for growth, and cells are not expected to be sensitive to the natural range in environmental temperature (Smith \& Sakshaug 1990, Reay et al. 2001). In addition, although at some coastal stations macronutrient concentrations were relatively low, throughout most of the area they exceeded concentrations found to be limiting for phytoplankton growth. Indeed, major localized macronutrient depletions coincided with the phytoplankton peaks (Figs. $4 \& 5$ ), and the close relationship between phytoplankton structure and $\left[\mathrm{NO}_{3}{ }^{-}+\mathrm{NO}_{2}{ }^{-}\right]$ and $\left[\mathrm{Si}(\mathrm{OH})_{2}\right]$ concentrations (Table 5) appears to be the result of the modification of macronutrient distributions by phytoplankton assimilation, as also reported in other studies (Holm-Hansen et al. 1989, Castro et al. 2002). Thus, neither temperature nor macronutrients are likely to have influenced the across-shelf phytoplankton changes.

The vertical phytoplankton distribution also changed along the onshore-offshore gradient (Figs. 1 \& 3). In the coastal and middle-shelf regions, chl a vertical profiles were closely related to water column density profiles (Fig. 3a,b), indicating a relatively uniform phytoplankton distribution within the upper mixed layer, and suggesting that phytoplankton were concentrated in the near-surface layer by physical stratification. In contrast, in the oceanic region, low chl a concentrations in the upper water column and maximum values at depths between 40 and $100 \mathrm{~m}$ (Fig. 3c), were not related to the vertical density profile. The vertical density profile showed a deep or not obvious mixed layer (Fig. 3c), indicating that water column stratification was not responsible for this vertical distribution of the phytoplankton.

Similar deep chl a maxima have been observed in Drake Passage, where it was hypothesized that phytoplankton growth was limited in near-surface waters due to low iron concentrations, and that the deep chl a maxima were the result of high iron concentrations in the 'winter water' mass (Holm-Hansen et al. 1994). We found the winter water present throughout most of our study area between 50 and $150 \mathrm{~m}$ (temperatures below $-1.0^{\circ} \mathrm{C}$ : Fig. 3). Defining the continental shelf slope to be at approximately the $500 \mathrm{~m}$ isobath (Hofmann et al. 1996), the oceanic region occupies the shelf slope and waters off the continental shelf (Fig. 1). Low iron concentrations limiting phytoplankton growth have been measured in several pelagic areas of the Southern Ocean, while high iron concentrations are expected over the continental shelf (Martin et al. 1990, de Baar et al. 1995). Therefore, these results provide support for the conjecture that in the oceanic region phytoplankton may have been limited by iron in near-surface waters and enhanced in the deep, iron-rich winter waters. An alternative possible scenario is that a phytoplankton bloom may have developed in association with the sea-ice edge in the oceanic region during early spring, as was observed in this region in another year by Smith et al. (2001). This bloom may have depleted the iron stock of surface waters, constraining all further phytoplankton growth to deep waters. In contrast, the presence of winter water appears to be less important to the phytoplankton assemblage of the continental shelf, where surface stratification of the water column (Fig. 3) and the probable presence of iron-rich surface waters may have allowed phytoplankton growth in the upper water column, under a favorable light regime.

During summer 1993, Prézelin et al. (2000) sampled the same area considered in this study, and observed diatom-enriched assemblages at stations in the oceanic region. Although they did not report the presence of deep chl a peaks, their results show an increment of chl $a$ and fucoxanthin concentrations at around $50 \mathrm{~m}$ depth (Prézelin et al. 2000, their Plate 1), indicating that the diatom-enhanced biomass they found was restricted to a deep layer within the water column. They associated this finding with upwelling of a macronutrient-rich water mass (UCDW), which may enhance diatom growth. However, the high proportion of diatoms in the subsurface layer can also be explained by the iron hypothesis that we suggest is part of the dynamics here, since enhanced diatom growth in iron-enriched waters has been experimentally demonstrated (de Baar et al. 1995, Boyd et al. 2000).

The dominant diatom species found in the oceanic region (Cluster 2: Fig. 7), Corethron criophyllum and small Fragilariopsis spp. (Table 3), are known pelagic species (Hasle 1969, Theriot \& Fryxell 1985, Villafañe et al. 1995). These same species were found in high biomass in deep waters of the Bransfield Strait shelf-break (Kang \& Lee 1995), close to the area where HolmHansen et al. (1994) found the presence of a deep chl a maximum. The comparison of these combined results for the Bransfield Strait with what we found in our study area suggests that the phytoplankton composition of the deep chl a peaks found in these 2 separate regions of the western Antarctic Peninsula is similar.

Concordance between our data and those of Prézelin et al. (2000) suggests that deep phytoplankton peaks may be a consistent year-to-year feature in the oceanic region. Furthermore, the finding of these same pattern in several years in the Bransfield Strait shelf-break (Holm-Hansen et al. 1994, Kang \& Lee 1995) suggests that the presence of a deep chl a layer might be typical all along the continental shelf slope of the western 
Antarctic Peninsula. This pattern contrasts with the vertical distribution pattern typically reported for Antarctic coastal phytoplankton, which is described as having the higher concentrations in the upper water column (Mitchell \& Holm-Hansen 1991, Priddle et al. 1994, Helbling et al. 1995, Smith et al. 1996, 1998, Dierssen et al. 2002, Varela et al. 2002). While iron limitation is a plausible hypothesis for these high-nutrient, low-chlorophyll (HNLC) waters, it should be noted that, to date, this hypothesis has not been tested by direct manipulation for this area. Therefore, further research is needed to understand what determines this particular distribution of the phytoplankton in the western Antarctic Peninsula, and the possible impact of the deep concentration of the phytoplankton in the trophic dynamics of pelagic waters of the Southern Ocean.

During January 1997, the abundance and grazing impact of krill and salps was relatively low in the oceanic region (Fig. 8, Table 4). Although Prézelin et al. (2000) suggested that Antarctic krill might prefer these offshore communities, krill grazing impact during January 1993 at the oceanic stations was very low (Ross et al. 1998), as found in this study. Furthermore, we can characterize the grazing impact in this region for other years in January (1993 to 1995). In all these years, krill grazing in the oceanic region was low-tozero, and salps were present in 1994, but not in either 1993 or 1995 (Ross et al. 1998). Thus, it appears that macrozooplankton impact is not important in this region. Previous studies showed the greater importance of protist grazers in iron-stimulated phytoplankton assemblages in pelagic waters of the Southern Ocean and other marine ecosystems (Boyd et al. 2000, Landry et al. 2000), which agrees with our finding of low macrozooplankton in this region.

\section{Mesoscale variability in open waters}

A final consideration of the phytoplankton distribution in open waters of the continental shelf is the variability detected near Renaud Island (Cluster 4a: Fig. 7b). The phytoplankton assemblage of this region was homogeneously distributed throughout the upper mixed layer (Fig. 3b), and was characterized by an increased abundance of unidentified phytoflagellates, diatoms, prasinophytes and dinoflagellates (Fig. 6). This composition is similar to that found by Prézelin et al. (2000) during the summer of 1993 in the same location, suggesting that this phytoplankton community may be consistently present there. They associated this assemblage with the upwelling of Upper Circumpolar Deep Water. We found temperature changes in the upper water column in this region (Fig. 2a), which may have been the result of upwelling processes, giving additional support to the hypothesis of Prézelin et al. (2000). Although these authors correlated the upwelling with 'unusual strong winds' and suggested that these events may be rare, observation of the same phenomena in 2 different years suggest that upwelling may be repeated every year in this region. The bottom topography is characterized by a deep channel in this region (Hofmann et al. 1996, Prézelin et al. 2000), probably providing a direct connection between this site and the outer shelf and favoring upwelling processes. During 1997, the abundance of both krill and salps was relatively high at stations with this phytoplankton assemblage (Fig. 8, Table 4), as also seen in this region during January 1993 (Ross et al. 1998). Thus, it appears that upwelling processes may have implications for the trophic-chain dynamics in restricted sites of the western Antarctic Peninsula as stated by Prézelin et al. (2000).

\section{Mesoscale variability alongshore}

This study has documented spatial variability in phytoplanktonic community composition, cell abundance and biomass in the inner shelf stations (Figs. $5 \& 6$ ), as indicated by the presence of 3 peaks in cell abundance (Fig. 5b) characterized by different algae assemblages: diatoms and Phaeocystis spp. in Marguerite Bay, unidentified phytoflagellates in Grandidier Channel, and unidentified phytoflagellates and Cryptomonas spp. near Anvers Island (Fig. 6).

The phytoplanktonic community of Marguerite Bay (Cluster 1: Fig. 7), was associated with the sea-ice edge, found in the southern part of Marguerite Bay during the sampling period (Ross \& Baker 1997). Diatom and Phaeocystis spp. dominance, as found in this region (Table 2, Fig. 6c,e), is common in phytoplankton blooms in the marginal sea-ice zone (Bianchi et al. 1992, Buma et al. 1992, Bidigare et al. 1996, Fiala et al. 1998). Furthermore, the dominant diatom species Odontella weisflogii, Eucampia antarctica, Thalassiosira spp. and Chaetoceros socialis (Table 3), are typical bloom-forming species in other coastal regions of the western Antarctic Peninsula also (Moline \& Prézelin 1996, Varela et al. 2002, Garibotti et al. 2003), and the co-occurrence of this particular diatom composition and Pyramimonas spp. in phytoplankton blooms has also been previously reported (Moline \& Prézelin 1996, Varela et al. 2002), suggesting a high similarity in the composition of the phytoplankton blooms of this part of the Southern Ocean.

The phytoplankton assemblages of Grandidier Channel and near Anvers Island, with very high abundance of unidentified phytoflagellates and crypto- 
phytes (Fig. 6), are noteworthy, since algae blooms dominated by small phytoplagellates have only occasionally been reported for the Southern Ocean (Bird \& Karl 1991, Jacques \& Panouse 1991, Buma et al. 1992, Kozlowski et al. 1995, Kopczynska 1996, Moline et al. 1997, Varela et al. 2002). However, this kind of bloom cannot be considered a peculiarity of the study area, since these blooms do not accumulate high biomass and can be detected only when cell abundance is calculated. Thus, their occurrence may have been overlooked in the Southern Ocean, since the methodology used in most ecological studies is based on biomass measurements only.

These 3 phytoplankton assemblages described alongshore are similar in composition and standing stock to the communities found in Palmer Basin (Anvers Island coast) during different stages of the seasonal phytoplankton succession (Holm-Hansen et al. 1989, Kozlowski et al. 1995, Moline \& Prézelin 1996, Moline et al. 1997). From south to north, they represent assemblages typically found in early spring (Marguerite Bay), late spring (Grandidier Channel) and summer (near Anvers Island). Thus, we hypothesize that the distribution of summer phytoplankton in nearshore waters reflects different stages of the seasonal succession of organisms. This pattern may have been the result of the fact that the onset of the seasonal phytoplankton cycle is closely related to sea-ice melting (Smith et al. 1996, Moline et al. 1997), and that the progressive southward retreat of sea-ice cover during spring and summer (Stammerjohn \& Smith 1996) must trigger the initiation of the phytoplankton succession at different times throughout the area, driving the variability of the coastal phytoplankton. This hypothesis is supported by the results of chl a remote-sensing by satellites, which showed a gradual movement of a pigment-enriched region from the northwest to the southeast of the area as the sea-ice retreated (Smith et al. 1998, 2001). The presence during summer of assemblages in different stages of succession has also been reported for a northern region of the western Antarctic Peninsula (Bode et al. 2002).

Assuming a seasonal progression of phytoplankton succession from north to south, as previously discussed, environmental conditions associated with these 3 phytoplankton assemblages may give more information of the phytoplankton dynamics in nearshore waters. Environmental conditions in Marguerite Bay showed high water column stability (Fig. 2c) and low krill abundance (Fig. 8a), both of which are considered as requisite for the development of a diatom bloom in the Southern Ocean (Bianchi et al. 1992, Kopczynska 1992, Boyd et al. 2000, Walsh et al. 2001). Moving north, in Grandidier Channel, water column stability was high (Fig. 2c) and krill had the highest grazing impact values of the area (Fig. 8a,c). This concentration of krill leads to speculation on the possible role of herbivory in determining the high phytoflagellate and low diatom abundance found in this region (Fig. 6). Antarctic krill actively select for diatoms (Haberman et al. 2003) and can completely strip diatom populations within a few hours (Meyer \& El-Sayed 1983, Alder et al. 1989, Ross et al. 1998). Thus, heavy selective grazing pressure by Antarctic krill could alter phytoplankton community composition, and may underlie the low diatom standing-stock found in Grandidier Channel. Furthermore, selective krill herbivory has been proposed as the most important factor determining the abrupt seasonal replacement of diatoms by phytoflagellates in coastal Antarctic waters (Karl 1993, Walsh et al. 2001). As discussed above, chl a remote-sensing analysis revealed that a phytoplankton bloom developed early in the year in Grandidier Channel in the wake of the retreating ice-edge. We also know that in the western Antarctic Peninsula blooms are due to diatoms (Holm-Hansen et al. 1989, Varela et al. 2002, Garibotti et al. 2003). Therefore, we postulate that this bloom may have recently disappeared due to high krill herbivory, leaving high $\mathrm{NH}_{4}{ }^{+}$concentrations (Fig. 4c) as evidence of the grazing, and fostering a bloom of phytoflagellates (Fig. 6). Since phytoflagellates are competitors of diatoms for nutrients and light (Walsh et al. 2001), selective herbivory on diatoms may have promoted the phytoflagellate bloom under conditions of high water column stability (Fig. 2c). In addition, krill can also graze on protozoans, the major herbivore of small flagellates (Smetacek et al. 1990, Walsh et al. 2001), a characteristic of this grazer that might also favor phytoflagellates. Therefore, we hypothesize that the phytoflagellate bloom in Grandidier Channel may represent a secondary stage of seasonal succession in this region, after the initial diatom bloom associated with the ice-edge.

In the third abundance peak, near Anvers Island (Fig. 5b), Cryptomonas spp. and unidentified phytoflagellates dominated (Fig. 6). Moline et al. (1997) reported the onset of a Cryptomonas spp. bloom at Palmer Basin occurring during early summer in this region, associated with glacial melting. Our results indicate that this cryptophyte bloom, found every summer at Palmer Station, is part of a more widespread assemblage, which extends to the west and south of Anvers Island (Fig. 6b), and the development of this cryptophyte assemblage in open waters may be related to a plume of freshwater modified by continental glacier melting moving offshore (Dierssen et al. 2002). In this northern region, salp abundance was high (Fig. 8b), suggesting a co-occurrence and potentially high grazing by this macrozooplankton group on cryptophytes. Although salps are not thought to be selective feeders (Pakhomov et al. 2002), salp fecal pel- 
lets containing high concentrations of cryptophytes have been found in other areas of the Southern Ocean (Detmer \& Bathmann 1997).

In summary, these 2 postulated interactions of the phytoplankton and zooplankton community are on different timescales. Krill grazing in the recent past is suggested as a possible mechanism to account for the lack of diatoms in Grandidier Channel, whereas the grazing of salps on cryptophyte blooms is suggested to be ongoing near Anvers Island. Testing such mechanisms requires some method of tracking changes in the communities over time. However, it is hypothesized here that both zooplankton groups may have an important influence on the replacement of algae groups alongshore and through their seasonal succession.

\section{Conclusions}

The results of this research have shown that the western Antarctic Peninsula coastal and shelf region is complex. Phytoplankton had high spatial variability on both large- and meso-scales. The main variability in the phytoplankton composition, abundance and biomass was observed along an onshore-offshore gradient, and superimposed on this pattern was high mesoscale variability in the phytoplankton assemblage structure. Comparison of our results with studies performed previously by other authors suggests that the distribution of summer phytoplankton within the area has a similar pattern from year to year. The variability of the phytoplankton community was related to differences in the local environmental parameters and reflected the different temporal stages of the seasonal succession of algae assemblages. These results can be summarized as follows: (1) water column stability appears to have had a dominant role in controlling phytoplankton variability along a gradient between the coast and oceanic waters. (2) Phytoplankton vertical distribution in the pelagic region showed a distinct deep maximum ( 40 to $100 \mathrm{~m}$ ) that was related to winter waters. Low iron concentration at the surface is hypothesized to cause this vertical chl a distribution of the phytoplankton. (3) Sea-ice dynamics appear to have a great influence over the coastal phytoplankton. The different phytoplankton assemblages found alongshore appear to be in different stages of the seasonal succession as a consequence of the progressive retreat of the sea-ice from the north to the south. (3) There was a close relationship between phytoplankton and zooplankton composition in inner-shelf waters of the area, with low diatom abundance in sites with high krill grazing, and high cryptophytes abundance in sites with high salp grazing. We hypothesize that krill grazing may have had a key role in determining the shift from a diatom bloom to a phytoflagellate bloom stage.
Acknowledgements. We would like to thank the crew of the RV 'Polar Duke' and Antarctic Support Associates, Inc. for their support during sampling. The members of the Palmer Long-Term Ecological Research program provided help and stimulating discussions during the cruise. We would like to thank W. Kozlowski, K. Sines, J. Jones and D. Menzies for sample collection. We thank Silvia Delgado for her help with data analysis and valuable comments, and Walter Helbling for critical comments and suggestions that improved the manuscript. This project was funded by the Office of Polar Programs, National Science Foundation, USA, grant 96-32763. I.A.G.'s work was supported by a doctoral fellowship of the Consejo Nacional de Investigaciones Científicas y Técnicas (CONICET), Argentina. This is Palmer LTER contribution \#237.

\section{LITERATURE CITED}

Alder V, Cuzin-Roudy J, Fransz G, Graneli E, Larsen J, Rabbani M, Thomsen H (1989) Macro- and micrograzing effects on phytoplankton communities. In: Hempel I, Schalk PH, Smetacek V (eds) The expedition Antarktis VII/3 (EPOS LEG 2) of RV 'Polarstern' in 1988/89. Ber Polarforsch 65:123-130

Baker KS, Fraser WR, Hofmann EE, Karl DM and 7 others (1996) The western Antarctic Peninsula region: summary of environmental and ecological processes. In: Ross $\mathrm{R}_{\text {, }}$ Hofmann E, Quetin L (eds) Foundations for ecosystem research in the western Antarctic Peninsula region. American Geophysical Union, Washington, DC, p 437-448

Bathmann UV, Scharek R, Klaas C, Dubischar CD, Smetacek V (1997) Spring development of phytoplankton biomass and composition in major water masses of the Atlantic sector of the Southern Ocean. Deep-Sea Res Part II 44:51-67

Bianchi F, Boldrin A, Cioce F, Diekmann G and 6 others (1992) Phytoplankton distribution in relation to sea ice, hydrography and nutrients in the northwestern Weddell Sea in early spring 1988 during EPOS. Polar Biol 12:225-235

Bidigare RR, Iriarte JL, Kang SH, Karentz D, Ondrusek ME, Fryxell GA (1996) Phytoplankton: quantitative and qualitative assessments. In: Ross R, Hofmann E, Quetin L (eds) Foundations for ecosystem research in the western Antarctic Peninsula region. American Geophysical Union, Washington, DC, p 173-198

Bird DF, Karl DM (1991) Massive prasinophyte bloom in northern Gearlache Strait. Antarct J US 26:152-154

Bode A, Castro CG, Doval MD, Varela M (2002) New and regenerated production and ammonium regeneration in the western Bransfield Strait region (Antarctica) during phytoplankton bloom conditions in summer. Deep-Sea Res Part II 49:787-804

Boyd PW, Watson AJ, Law CS, Abraham ER and 31 others (2000) A mesoscale phytoplankton bloom in the polar Southern Ocean stimulated by iron fertilization. Nature 407:695-702

Brandini FP, Kutner MBB (1986) Composition and distribution of summer phytoplankton in the Brasfield Strait, Antarctica. An Acad Bras Ciênc 58:3-11

Buma AGJ, Gieskes WWC, Thomsen HA (1992) Abundance of Cryptophyceae and chlorophyll $b$-containing organisms in the Weddell-Scotia Confluence area in the spring of 1988. Polar Biol 12:43-52

Castro CG, Ríos AF, Doval MD, Pérez FF (2002) Nutrient utilization and chlorophyll distribution in the Atlantic sector of the Southern Ocean during austral summer 1995-96. Deep-Sea Res Part II 49:623-641 
de Baar HJW, de Jong JTM, Bakker DCE, Löscher BM, Veth C, Bathmann U, Smetacek V (1995) Importance of iron for plankton blooms and carbon dioxide drawdown in the Southern Ocean. Nature 373:412-415

Detmer AE, Bathmann UV (1997) Distribution patterns of autotrophic pico- and nanoplankton and their relative contribution to algal biomass during spring in the Atlantic sector of the Southern Ocean. Deep-Sea Res Part II 44: 299-320

Dierssen HM, Smith RC, M Vernet (2002) Glacial meltwater dynamics in coastal waters west of the Antarctic peninsula. Proc Natl Acad Sci USA 99:1790-1795

Fiala M, Semeneh M, Oriol L (1998) Size-fractionated phytoplankton biomass and species composition in the Indian sector of the Southern Ocean during austral summer. J Mar Syst 17:179-194

Garibotti IA, Vernet M, Kozlowski W, Ferrario M (2003) Composition and biomass of phytoplankton assemblages in coastal Antarctic waters: a comparison of chemotaxonomic and microscopic analyses. Mar Ecol Prog Ser 247:27-42

Haberman KL, Quetin LB, Ross RM (2003) Diet of the Antarctic krill (Euphausia superba Dana). II. Selective grazing on mixed phytoplankton assemblages. J Exp Mar Biol Ecol 283:97-113

Hasle GR (1969) An analysis of the phytoplankton of the Pacific Southern Ocean: abundance, composition and distribution during the Brategg expedition, 1947-1948. Hvalråd Skr 52:1-168

Helbling EW, Villafañe VE, Holm-Hansen O (1995) Variability of phytoplankton distribution and primary production around Elephant Island, Antarctica, during 1990-1993. Polar Biol 15:233-246

Hillebrand H, Dürselen CD, Kirschtel D, Pollingher U, Zohary $\mathrm{T}$ (1999) Biovolume calculation for pelagic and benthic microalgae. J Phycol 35:403-424

Hofmann EE, Klinck JM (1998) Thermohaline variability of the waters overlying the west Antarctic Peninsula continental shelf. In: Jacobs S, Weiss R (eds) Ocean, ice and atmosphere: interactions at the Antarctic continental margin. American Geophysical Union, Washington, DC, p 67-81

Hofmann EE, Klinck JM, Lascara CM, Smith DA (1996) Water mass distribution and circulation west of the Antarctic Peninsula and including Bransfield Strait. In: Ross R, Hofmann E, Quetin L (eds) Foundations for ecosystem research in the western Antarctic Peninsula region. American Geophysical Union, Washington, DC, p 61-80

Holm-Hansen O, Mitchell BG, Hewes CD, Karl DM (1989) Phytoplankton blooms in the vicinity of Palmer Station, Antarctica. Polar Biol 10:49-57

Holm-Hansen O, Amos AF, Silva N, Villafañe VE, Helbling EW (1994) In situ evidence for a nutrient limitation of phytoplankton growth in pelagic Antarctic waters. Antarct Sci 6:315-324

Jacques G, Panouse M (1991) Biomass and composition of size fractionated phytoplankton in the Weddell-Scotia Confluence area. Polar Biol 11:315-328

Johnson KS, Petty RL, Tomsen J (1985) Flow injection analysis in seawater macronutrients. In: Zirio A (ed) Mapping strategies in chemical oceanography. Adv Chem Ser 209: $7-30$

Jongman, RHG, ter Braak CJF, van Tongeren OFR (1995) Data analysis in community and landscape ecology. Cambridge University Press, Cambridge

Kang SH, Lee SH (1995) Antarctic phytoplankton assemblage in the western Bransfield Strait region, February 1993: composition, biomass, and mesoscale distributions. Mar
Ecol Prog Ser 129:253-267

Karl DM (1993) Microbial processes in the Southern Ocean. In: Friedmann EI (ed) Antarctic microbiology. John Wiley \& Sons, New York, p 1-63

Kopczynska EE (1992) Dominance of microflagellates over diatoms in the Antarctic areas of deep vertical mixing and krill concentrations. J Plankton Res 14:1031-1054

Kopczynska EE (1996) Annual study of phytoplankton in Admiralty Bay, King George Island, Antarctica. Pol Polar Res 17:151-164

Kozlowski W, Vernet M, Lamerdin SK (1995) Palmer LTER: predominance of cryptomonads and diatoms in Antarctic coastal waters. Antarct J US 30:267-268

Landry MR, Constantinou J, Latasa M, Brown SL, Bidigare RR, Ordrusek ME (2000) Biological response to iron fertilization in the eastern equatorial Pacific (IronEx II). III. Dynamics of phytoplankton growth and microzooplankton grazing. Mar Ecol Prog Ser 201:57-72

Lorenzo LM, Arbones B, Figueiras FG, Tilstone GH, Figueroa FL (2002) Photosynthesis, primary production and phytoplankton growth rates in Gearlache and Bransfield Straits during Austral summer: cruise FRUELA 95. Deep-Sea Res Part II 49:707-721

Marchant HJ, Murphy EJ (1994) Interactions at the base of the Antarctic food web. In: El-Sayed SZ (ed) Southern Ocean ecology: the BIOMASS perspective. Cambridge University Press, New York, p 267-285

Martin JH, Gordon RM, Fitzwater SE (1990) Iron in Antarctic waters. Nature 345:156-158

Mengesha S, Dehairs F, Fiala M, Elskens M, Goeyens L (1998) Seasonal variation of phytoplankton structure and nitrogen uptake regime in the Indian sector of the Southern Ocean. Polar Biol 20:259-272

Meyer MA, El-Sayed SZ (1983) Grazing of Euphausia superaba Dana on natural phytoplankton populations. Polar Biol 1:193-197

Mitchell BG, Holm-Hansen O (1991) Observations and modeling of the Antarctic phytoplankton crop in relation to mixing depth. Deep-Sea Res 38:981-1007

Moline MA, Prézelin BB (1996) Long-term monitoring and analyses of physical factors regulating variability in coastal Antarctic phytoplankton biomass, in situ productivity and taxonomic composition over subseasonal, seasonal and interannual time scales. Mar Ecol Prog Ser 145: 143-160

Moline MA, Prézelin BB, Schofield O, Smith RC (1997) Temporal dynamics of coastal Antractic phytoplankton: environmental driving forces and impact of a 1991/92 summer diatom bloom on the nutrient regimes. In: Battaglia $B$, Valencia J, Walton DWH (eds) Antarctic communities species, structure and survival. Cambridge University Press, New York, p 67-72

Montagnes DJS, Franklin DJ (2001) Effect of temperature on diatom volume, growth rate, and carbon and nitrogen content: reconsidering some paradigms. Limnol Oceanogr 46: 2008-2018

Montagnes DJS, Berges JA, Harrison PJ, Taylor FJR (1994) Estimating carbon, nitrogen, protein, and chl a from volume in marine phytoplankton. Limnol Oceanogr 39: 1044-1060

Niiler PP, Amos A, Hu JH (1991) Water masses and $200 \mathrm{~m}$ relative geostrophic circulation in the western Bransfield Strait region. Deep-Sea Res 38:943-959

Pakhomov EA, Froneman PW, Perissinotto R (2002) Salp/krill interactions in the Southern Ocean: spatial segregation and implications for the carbon flux. Deep-Sea Res Part II 49:1881-1907 
Pielou EC (1984) The interpretation of ecological data: a primer on classification and ordination. John Wiley \& Sons, New York

Prézelin BB, Hofmann EE, Mengelt C, Klinck JM (2000) The linkage between Upper Circumpolar Deep Water (UCDW) and phytoplankton assemblages on the west Antarctic Peninsula continental shelf. J Mar Res 58:165-202

Priddle J, Smetacek V, Bathmann U (1992) Antarctic marine primary production, biogeochemical carbon cycles and climatic change. Philos Trans R Soc Lond B 338:289-297

Priddle J, Brandini F, Lipski M, Thorley MR (1994) Pattern and variability of phytoplankton biomass in the Antarctic Peninsula region: an assessment of the BIOMASS cruises. In: El-Sayed SZ (ed) Southern ocean ecology: the BIOMASS perspective. Cambridge University Press, New York, p 49-61

Quetin LB, Ross RM, Frazer TK, Haberman KL (1996) Factors affecting distribution and abundance of zooplankton, with an emphasis on Antarctic krill, Euphausia superba. In: Ross R, Hofmann E, Quetin L (eds) Foundations for ecosystem research in the western Antarctic Peninsula region. American Geophysical Union, Washington, DC, p 257-371

Reay DS, Priddle J, Nedwell DB, Whitehouse MJ, Ellis-Evans JC, Deubert C, Connelly DP (2001) Regulation by low temperature of phytoplankton growth and nutrient uptake in the Southern Ocean. Mar Ecol Prog Ser 219:51-64

Ross RM, Baker KS (1997) Palmer LTER: annual January cruise for 1997 (PD97-1). Antarct J US 32:143-146

Ross RM, Quetin LB, Haberman KL (1998) Interannual and seasonal variability in short-term grazing impact of Euphausia superba in nearshore and offshore waters west of the Antarctic Peninsula. J Mar Syst 17:261-273

Ross RM, Quetin LB, Baker KS, Vernet M, Smith RC (2000) Growth limitation in young Euphausia superba under field conditions. Limnol Oceanogr 45:31-43

Smetacek V (1996) Biodiversity and production in the water mass. In: Hempel G (ed) The ocean and the poles. Fischer Verlag, Jena, p 207-216

Smetacek V, Scharek R, Nöthig EM (1990) Seasonal and regional variation in the pelagial and its relationship to the life history cycle of krill. In: Kerry KR, Hempel G (eds) Antarctic ecosystems, ecological change and conservation. Springer-Verlag, Heidelberg, p 103-114

Smith RC, Baker KS, Dustan P (1981) Fluorometric techniques for the measurement of oceanic chlorophyll in the support of remote sensing. Scripps Institution of Oceanography, University of California (Ref 81-17)

Smith RC, Baker KS, Fraser WR, Hofmann EE and 7 others (1995) The Palmer LTER: a long-term ecological research program at Palmer Station, Antarctica. Oceanography 8: $77-86$

Smith RC, Dierssen HM, Vernet M (1996) Phytoplankton biomass and productivity in the western Antarctic Peninsula region. In: Ross R, Hofmann E, Quetin L (eds) Foundations for ecosystem research in the western Antarctic Peninsula region. American Geophysical Union, Washington, DC, p 333-356

Editorial responsibility: Otto Kinne (Editor),

Oldendorf/Luhe, Germany
Smith RC, Baker KS, Vernet M (1998) Seasonal and interannual variability of phytoplankton biomass west of the Antarctic Peninsula. J Mar Syst 17:229-243

Smith RC, Baker KS, Dierssen HM, Stammerjohn SE, Vernet M (2001) Variability of primary production in an Antarctic marine ecosystem as estimated using a multi-scale sampling strategy. Am Zool 41:40-56

Smith WO, Nelson DM (1985) Phytoplankton bloom produced by receding ice edge in the Ross Sea: spatial coherence with the density field. Science 227:163-166

Smith WO Jr, Sakshaug E (1990) Polar phytoplankton. In: Smith WO Jr (ed) Polar oceanography. Part B. Chemistry, biology, and geology. Academic Press, London, p 477-525

Stammerjohn SE, Smith RC (1996) Spatial and temporal variability of western Antarctic Peninsula sea-ice coverage. In: Ross R, Hofmann E, Quetin L (eds) Foundations for ecosystem research in the western Antarctic Peninsula region. American Geophysical Union, Washington, DC, p 81-104

ter Braak CJF (1994) Canonical community ordination. Part I. Basic theory and linear methods. Ecoscience 1:127-140

Theriot E, Fryxell GA (1985) Multivariate statistical analysis of net diatom species distributions in the southwestern Atlantic and Indian Ocean. Polar Biol 5:23-30

Throndsen J (1978) Preservation and storage. In: Sournia A (ed) Phytoplankton manual. Monographs on oceanography methodology 6. UNESCO, Paris, p 69-74

Tréguer P, Jacques G (1992) Dynamics of nutrients and phytoplankton, and fluxes of carbon, nitrogen and silicon in the Antarctic Ocean. Polar Biol 12:149-162

Utermöhl H (1958) Zur Vervollkommung der quantitativen Phytoplankton Methodik. Mitt Int Ver Theor Angew Limnol 9:1-38

Varela M, Fernández E, Serret P (2002) Size-fractionated phytoplankton biomass and primary production in the Gearlache and south Bransfield Straits (Antarctic Peninsula) in the austral summer 1995-1996. Deep-Sea Res Part II 49:749-768

Villafañe VE, Helbling EW, Holm-Hansen O (1995) Spatial and temporal variability of phytoplankton biomass and taxonomic composition around Elephant Island, Antarctica, during the summers of 1990-1993. Mar Biol 123: 677-686

von Bröckel K (1981) The importance of nanoplankton within the pelagic Antarctic ecosystem. Kiel Meeresforsch Sonderh 5:61-67

Walsh JJ, Dieterle DA, Lenes J (2001) A numerical analysis of carbon dynamics of the Southern Ocean phytoplankton community: the roles of light and grazing in effecting both sequestration of atmospheric $\mathrm{CO}_{2}$ and food availability to larval krill. Deep-Sea Res Part I 48:1-48

Waters KJ, Smith RC (1992) Palmer LTER: a sampling grid for the Palmer LTER program. Antarct J US 27:236-239

Weber LH, El-Sayed SZ (1987) Contributions of the net, nanoand picoplankton to the phytoplankton standing crop and primary productivity in the Southern Ocean. J Plankton Res 9:973-994

Submitted: October 17, 2002; Accepted: May 8, 2003

Proofs received from author(s): September 17, 2003 